Canadian Science Publishing

Canadian Journal of Earth Sciences Revue canadienne des sciences de la Terre

\title{
Modelling Seabed Shear Stress, Sediment Mobility and Sediment Transport in the Bay of Fundy
}

\begin{tabular}{|r|l|}
\hline Journal: & Canadian Journal of Earth Sciences \\
\hline Manuscript ID: & cjes-2014-0211.R1 \\
\hline Manuscript Type: & Article \\
\hline Complete List of Authors: & $\begin{array}{l}\text { Li, Michael Z.; Bedford Institute of Oceanography, Geological Survey of } \\
\text { Canada (Atlantic) } \\
\text { Hannah, Charles G.; Department of Fisheries and Oceans Canada, } \\
\text { Perrie, William A.; Department of Fisheries and Oceans Canada, } \\
\text { Tang, Charles; Department of Fisheries and Oceans Canada, } \\
\text { Prescott, Robert H.; Prescott and Zou Consulting, 6 Glenn Dr. } \\
\text { Greenberg, David A.; Department of Fisheries and Oceans Canada, }\end{array}$ \\
\hline Keyword: & $\begin{array}{l}\text { tidal current and waves, shear stresses, sediment mobility, sediment } \\
\text { transport, Bay of Fundy }\end{array}$ \\
\hline \multicolumn{2}{|c|}{} \\
\hline
\end{tabular}




\title{
Modelling Seabed Shear Stress, Sediment Mobility and Sediment Transport In the Bay of Fundy
}

\author{
Michael Z. Li ${ }^{*}$, Charles G. Hannah ${ }^{2}$, William A. Perrie ${ }^{3}$, Charles C.L. Tang ${ }^{3}$, \\ Robert H. Prescott ${ }^{4}$ and David A. Greenberg ${ }^{3}$ \\ ${ }^{1}$ Geological Survey of Canada (Atlantic), P.O. Box 1006, Dartmouth, Nova Scotia B2Y 4A2 \\ ${ }^{2}$ Department of Fisheries and Oceans Canada, Sidney, B.C. V8L 4B2 \\ ${ }^{3}$ Department of Fisheries and Oceans Canada, P.O. Box 1006, Dartmouth, Nova Scotia B2Y 4A2 \\ ${ }^{4}$ Prescott and Zou Consulting, 6 Glenn Dr., Halifax, Nova Scotia B3M 2B9 \\ *Corresponding author: Tel.:+19024269459; Fax:+19024266186; E-mail: mli@nrcan.gc.ca
}




\begin{abstract}
Information about seabed stability and sediment dynamics is part of the fundamental geoscience knowledge required for the extraction of tidal energy in the Bay of Fundy and for the integrated management of the Bay. Waves, tidal currents and wind-driven and circulation currents were obtained from oceanographic models to assess the wave and current processes for the broader Bay of Fundy. The wave and current outputs were coupled with observed grain size in a sediment transport model to predict, for the first time, the seabed shear stresses, sediment mobility, and sediment transport patterns for the entire Bay. The root mean square tidal current, highest in the upper Bay $\left(>1.4 \mathrm{~m} \mathrm{~s}^{-1}\right)$, is reduced to moderate in the central Bay $\left(0.5-0.8 \mathrm{~m} \mathrm{~s}^{-1}\right)$ and decreases further in the outer Bay $\left(0.2-0.5 \mathrm{~m} \mathrm{~s}^{-1}\right)$. The maximum tidal current occurs in the Minas Passage and is greater than $5 \mathrm{~m} \mathrm{~s}^{-1}$. The mean significant wave height, in contrast, is the greatest in the outer Bay $(\sim 1.3 \mathrm{~m})$ and gradually decreases to the northeast in the central and upper Bay $(<0.5 \mathrm{~m})$. Seabed shear in the Bay of Fundy is mostly due to tides, and wave effects are only important in coastal areas. The strongest mean shear velocity of $10 \mathrm{~cm} \mathrm{~s}^{-1}$ occurs in the Minas Passage area. Strong shear velocity of $4-5 \mathrm{~cm} \mathrm{~s}^{-1}$ also occurs in Minas Basin, in the central Bay, and in the narrows around Grand Manan Island. Sediment mobilization in the Bay of Fundy is predominantly by tidal current. Mobilization frequency is $>30 \%$ of time over most of the Bay and reaches $100 \%$ of the time in some areas. The maximum total-load sediment transport rate under spring tide can reach $\sim 5 \mathrm{~kg} \mathrm{~m}^{-1} \mathrm{~s}^{-1}$ and is to the northeast during flood and to the southwest during ebb. Net sediment transport flux, however, is dominantly to the northeast and reaches $2 \mathrm{~kg} \mathrm{~m}^{-1} \mathrm{~s}^{-1}$. Eddies of net transport are found to occur around headlands and at the narrows of Grand Manan Island, largely due to the occurrence of eddies of residual tidal flows. The regional distribution of substrate types and bedform fields and patterns of seabed erosion and deposition are well correlated with tidal current strength and sediment transport patterns.
\end{abstract}

Key words: tidal current; waves; shear stresses; sediment mobility; sediment transport; Bay of Fundy; 


\section{Introduction}

The Bay of Fundy, located on the east coast of Canada (Fig. 1), has been of great economic, ecological and scientific significance because of its world-renowned tides, unique seabed geology, abundant marine resources and diverse ecosystems (Percy et al. 1997). The Fundy Gulf of Maine - Georges Bank system forms one of the world's most biologically productive ecosystems (Jacques Whitford 2008). The Bay of Fundy shares the world's largest recorded tides (16.3 m; O'Reilly et al. 2005) with Ungava Bay. In recent years there has been a renewed interest in exploiting the huge amount of tidal energy in the Bay of Fundy (e.g. Karsten et al. 2008; Hasegawa et al. 2011). All these economic and environmental issues demand sound knowledge of the nearbed hydrodynamics, seabed sediment mobility, and sediment transport processes for the region.

From the global sediment dynamics perspective, observational and modeling studies in the last 20 to 30 years have established that waves, tidal currents, and wind-driven currents are the significant processes causing sediment transport in coastal and shelf environments (e.g. Butman et al. 1979; Cacchione and Drake 1990; Nittrouer and Wright 1994; Harris and Wiberg 2001). In areas of complex coastline, topography, and sediment types, understanding of regional and longterm sediment transport is impossible with observations alone. Numerical modelling of sediment transport has been widely applied to examine sediment transport processes and patterns with detailed spatial and temporal resolutions (e.g. Holt and James 1999; Zhang et al. 1999; Davies and Xing 2002; Luff and Moll 2004; Harris et al. 2008; Ulses et al. 2008; Warner et al. 2008a). These simulations are often limited to assuming uniform grain sizes and lack adequate observational data for model verification (Warner et al. 2008b). Given the great variations in wave and current processes and seabed sediment characteristics, sediment transport modelling is still needed in coastal and shelf seas to examine the influence of variation in seabed geology and the relative importance of wave and current processes. Recently numerical models have been applied in assessing tidal energy resources and impacts of tidal energy extraction (e.g. Karsten et al. 2008; Mulligan et al. 2013; Martin-Short et al. 2015). Numerical models have also been used 
to regionalize seabed disturbance and sediment mobilization on continental shelves for habitat classification and for understanding the geo-environment control of habitat distribution (PorterSmith et al. 2004; Hemer 2006). These studies have either used wave, ocean current, and tidal forcing that were calculated independently, an approach which fails to use the combined wavecurrent shear stress due to the effect of nonlinear wave-current interaction, or only quantified the seabed disturbance level based on the combined wave-current shear stress without explicit sediment mobilization calculation. Therefore universal indices for absolute quantification of seabed disturbance and sediment mobility, integrating both the magnitude and frequency of these processes, do not yet exist.

In the Bay of Fundy, perhaps more than in other marine areas, oceanographic, sedimentological and biological processes are inextricably intertwined and must be considered together for a proper understanding of the physical processes and ecosystem dynamics. A consensus exists among researchers that while physical oceanographic processes play a critical role in structuring the marine environment in the Bay, it is the dynamics of the sediments that are the key to understanding the functioning of its ecosystems (Percy et al. 1997). The hydrodynamic tidal processes in the Bay of Fundy are well studied through hydrodynamic models and field observations (e.g. Greenberg 1979; Lynch et al. 1996; and the review of Greenberg 1984). However, regional knowledge of bed shear stresses and sediment transport is quite limited. Most of our understanding of sediment transport was derived from observations and sediment budget analyses for local basins and estuaries two to three decades ago (e.g. Amos and Joice 1977; Dalrymple et al. 1978; Amos 1987). More recently, Fader (1997) assessed surficial sediment stratigraphy, aggregate resources, and seabed dynamics of the upper Bay of Fundy using data from the multibeam bathymetric mapping system. Duffy et al. (2004) used current measurements and repeat multibeam bathymetric surveying to investigate the migration of sand dunes on a banner bank in the central Bay of Fundy. Li et al. (2014) have integrated multibeam sonar mapping, geological surveys, tidal current and sediment transport model calculations to study the geomorphology and sediment transport processes over large bedforms near Cape Split in the upper Bay of Fundy. 
Numerical modelling studies of sediment transport in the Bay of Fundy are very sparse. Greenberg and Amos (1983) combined a M2 tidal model and sediment budget analysis to model sediment concentration and deposition impacted by the construction of a tidal power barrage in Minas Basin. Sediment transport flux was not modeled. In a study of the stability and dispersion of dredged material at an offshore disposal site in the central Bay of Fundy, Li et al. (2009a) integrated a tidal model with a sediment transport model to study the tidal current and sediment transport patterns for the region around the disposal site. Wu et al. (2011a) recently modelled sediment transport for Minas Channel and Minas Basin in the upper Bay of Fundy. However, bedload transport was calculated from an algorithm formulated for alluvial flows and the suspended load transport was partially modelled using model-predicted tidal currents and measured surface sediment concentration derived from remote-sensing images. Tao et al. (2014) used satellite observations and numerical modelling to understand the spatial-temporal variability of surficial suspended matter concentrations in Minas Basin. Previous reviews have identified the critical need for integrated hydrodynamics and sediment transport models that can simulate sediment movement and distribution patterns for the entire Bay of Fundy (Fader 1997; Percy et al. 1997). This knowledge gap still exists, and predictions of seabed shear stress and sediment transport patterns for the entire Bay of Fundy are presently not available. In the present paper, waves, tidal currents, wind-driven and circulation currents generated from oceanographic models were coupled with observed grain size in a sediment transport model to predict the seabed shear stresses, sediment mobility, and sediment transport patterns for the broader Bay of Fundy (see Fig. 1 for the study area). The shear stresses, including combined wave-current stress, are compared with bedload threshold based on observed grain size to derive innovative indices that quantify the seabed disturbance and sediment mobilization incorporating both the magnitude and frequency of these processes. The modelling study addresses the following scientific issues (1) magnitude and spatial variation of waves and tidal currents, (2) regional patterns of seabed shear stress, sediment mobility and sediment transport, (3) the relative impacts from waves, tidal currents, and circulation current, and (4) implications of model results to substrate and seabed feature distributions in the Bay of Fundy. 


\section{Methods}

\section{Tidal model}

Tidal currents were derived from a tidal model developed for the Scotian Shelf and Bay of Fundy region (Dupont et al. 2005). This finite-element model includes 10 tidal constituents (M2, $\mathrm{N} 2, \mathrm{~S} 2, \mathrm{~K} 1, \mathrm{O} 1, \mathrm{~K} 2, \mathrm{~L} 2,2 \mathrm{~N} 2$, NU2, and M4), and has a variable spatial resolution from $200 \mathrm{~m}$ in coastal areas to $\sim 20 \mathrm{~km}$ at the mouth of the Bay (Fig. 2a). The model uses a quadratic drag law for dissipation and the standard drag coefficient for vertically averaged tidal models, $C_{d}=2.5 \times$ $10^{-3}$. A detailed description of the model can be found in Dupont et al. (2005). The model was run for the 3 year period of September 12002 to August 312005 and the output was hourly depth-averaged tidal current on the unstructured grid shown in Figure 2a. The residual tidal current field was estimated using a separate model run that only included the M2 component which dominates the tides in the region.

Dupont et al. (2005) compared the modelled amplitude and phase of the five major constituents (M2, N2, S2, K1, O1) to that observed at 12 stations in the Bay of Fundy for overall validation of the tidal model. The amplitude and phase errors for the dominant M2 constituent are quite small with a root-mean-square (RMS) amplitude error of $0.14 \mathrm{~m}$ and a RMS phase error of $2.6^{\circ}$. Relative to the RMS M2 amplitude of $4.6 \mathrm{~m}$, the amplitude error is about $3 \%$. The modelled currents were compared with the observations at the 4 locations in the Bay of Fundy where they were available (Dupont et al. 2005). For the M2 constituent with amplitude of $1 \mathrm{~m} \mathrm{~s}^{-}$ ${ }^{1}$, the velocity prediction errors were 0.05 to $0.12 \mathrm{~m} \mathrm{~s}^{-1}$ or about 5 to $12 \%$. The errors for the other constituents were smaller; for $(\mathrm{N} 2, \mathrm{~S} 2, \mathrm{~K} 1, \mathrm{O} 1)$ they were about $\left(0.03 \mathrm{~m} \mathrm{~s}^{-1}, 0.02 \mathrm{~m} \mathrm{~s}^{-1},<\right.$ $0.01 \mathrm{~m} \mathrm{~s}^{-1},<0.01 \mathrm{~m} \mathrm{~s}^{-1}$ ) respectively. For the M4 constituent which is important for the tidal asymmetry, the observed major-axis currents were between 0.02 and $0.06 \mathrm{~m} \mathrm{~s}^{-1}$ (Godin, 1968). The modelled M4 currents were within $20 \%$ of the observations. The observed and modelled phases for the M4 constituent were generally within $10^{\circ}$. 


\section{Wave model}

The WAVEWATCHIII ${ }^{\circledR}$ model (version 2.22, Tolman 2002; denoted as WW3 hereafter) was used for wave predictions. The sub-domain of the wave model for the Bay of Fundy had a $0.2^{\circ}$ resolution and was nested inside a coarse grid of $1^{\circ}$ resolution covering an extended area of the Northwest Atlantic. For the Bay of Fundy sub-domain, the wave model was driven with the wind data from the Meteorological Service of Canada 50-year wind and wave hindcast data (MSC50; Swail et al. 2006). The model outputs were 3 hourly significant wave height, peak wave period, and mean wave (toward) direction at each grid point for the modelled 3 year period.

WW3 has been used for operational routine forecasts in the Bay of Fundy and Gulf of Maine since 2001, in both the Gulf of Maine Ocean Observing System (GoMOOS), and the Northeastern Regional Association of Coastal Ocean and Observing Systems (NERACOOS). Over the years, WW3 has been continually monitored and updated, as new versions have been released by the US weather service (NOAA). In particular, WW3 has been used in a recent modeling inter-comparison study (Perrie et al. per. comm.) focusing on three intense nor'easters that caused extensive coastal damages. Relative to buoy observations along the Northeast coast of USA, the model was shown to have a RMS error of $0.5 \mathrm{~m}$ and $3.6 \mathrm{~s}$, and bias of $-0.15 \mathrm{~m}$ and $2.2 \mathrm{~s}$, for significant wave heights and peak periods respectively. These results are comparable to those of other modern wave models, such as an unstructured grid version of WW3 described by Roland et al. (2012), and an unstructured version of SWAN wave model described by Qi et al. (2009).

\section{Ocean circulation model}

Ocean currents were computed from the Canadian East Coast Ocean Model (CECOM), a 3-D coupled ice-ocean circulation model for the east coast of Canada (Tang et al. 2008). The model grid has a $0.1^{\circ}$ horizontal resolution and 29 levels in the vertical coordinate. The ocean component of the model is based on the Princeton Ocean Model (POM) and the ice component is 
based on a modified Hibler model (Yao et al. 2000). The model was driven by wind stress, barometric pressure, heat and moisture fluxes calculated from 3-hourly NARR (The NCEP North American Regional Reanalysis) atmospheric parameters from NOAA. The model was initialized using the monthly temperature and salinity climatologies computed from an objective analysis of historical data archived at Bedford Institute of Oceanography. The modelled temperature and salinity fields were nudged toward the climatologies with a restoring time of 180 days. The model was run for the 3 year period of 2002 to 2005 to generate depth-averaged and 3 dimensional currents at 3-hour interval. The outputs of the model include wind-driven currents, density currents and currents generated by remote forcing. In this paper, we shall term the CECOM-generated currents "circulation currents".

Extensive efforts have been made to validate CECOM on annual (Wu et al. 2012) and shortterm (Wu et al. 2011b) time scales. CECOM simulated currents and observed currents at fixed locations and depths in several regions of the eastern Canadian seas were compared using two methods - a qualitative method based on visual comparisons and a quantitative method based on statistical analysis (Wu et al. 2012). The results indicate that the major features of the current fields from observations are reproduced successfully by the model. Estimates of volume transport through several sections based on data were reproduced by the model reasonably well. On shorter time scales, good agreement in both current speed and direction was obtained between the model simulations and current meter measurements during a storm over the eastern Canadian seas (Wu et al. 2011b). The mean error for the mean speed predicted at several depths was $7 \%$ relative to a mean speed magnitude of $0.16 \mathrm{~m} \mathrm{~s}^{-1}$ and the mean error for the maximum speed was $12 \%$ relative to a maximum speed magnitude of $0.36 \mathrm{~m} \mathrm{~s}^{-1}$.

\section{Bathymetry and grain size}

Irregular grid bathymetry of the tidal model was adopted as the depth data for seabed shear stress and sediment transport calculation (Fig. 2a). Mean grain size data based on seabed samples were extracted from the Geological Survey of Canada (GSC) Expedition Database. It should be 
noted that the GSC grain size data do not extend to the intertidal flats and channels of the model domain. These data were cleaned, quality controlled and interpolated onto the unstructured tidal model grid (Fig. 2b) to be used in the sediment transport model. The upper Bay of Fundy is dominated by medium to coarse sand. The middle and lower Bay are mostly covered by coarse sand and gravel except the basin to northeast of Grand Manan Island which is predominantly mud (Fig. 2b).

\section{Seabed shear stress, sediment mobility, and sediment transport computation}

The wave model data with $0.2^{\circ}$ resolution and the ocean model output with $0.1^{\circ}$ resolution were interpolated to conform to the unstructured grid of the tidal model data. The wave and ocean current data were also interpolated temporally to hourly interval. The hourly depthaveraged ocean current was added to the depth-averaged tidal current to derive the total current for each grid point. The ocean model does not include residual tidal currents. The residual tidal current from the tidal model was added to the hourly ocean current, and the magnitude of the current so derived was averaged for one year to derive the mean circulation current magnitude.

The depth-averaged tidal and total currents were taken as the near-bottom currents at $1 \mathrm{~m}$ above seabed. The wave and current data so derived, together with depth and observed grain size, were used in a combined-flow, continental shelf sediment transport model SEDTRANS (Li and Amos 2001) to compute the bed shear stresses for tidal current, waves, circulation current, and combined wave-current cases. At each grid point, the modelled hourly shear stress under various cases was compared with the critical shear stress for the initiation of bedload transport to derive the time percent that the critical shear stress was exceeded (threshold exceedance) for the modelled three year period. This provides the frequency of sediment mobilization by various oceanographic processes. The critical shear stress for bedload transport, $\tau_{\mathrm{cr}}$, was calculated from the Yalin method according to Miller et al. (1977). Only sediment mobility results averaged over the 3 year period were presented in this paper and therefore seasonable variability in seabed stress and sediment mobility (e.g. Tao et al. 2014) is not reflected. 
SEDTRANS is a calibrated and widely-used one dimensional computer model that predicts the boundary layer dynamics and sediment transport on continental shelves and in coastal environments for either steady currents or combined wave-current flows (Li and Amos 2001; Bastos et al. 2004; Hemer 2006). Comparisons of measured and modelled bedload transport rates over fine and medium sands showed that the error of the model-predicted sediment transport rate is less than a factor of 5 under complex combined wave and current conditions ( $\mathrm{Li}$ et al. 1997; Li and Amos 2001). Application of the model at a disposal site in the Bay of Fundy demonstrated reasonable magnitudes and transition of transport rates over mixed sand and cohesive sediments (Parrott et al. 2002; Li et al. 2009a). Calibration of a slightly modified version of SEDTRANS also showed that model-predicted cohesive sediment concentrations are typically within $20 \%$ of the measured values using annular flumes in the field (Neumeier et al. 2008). For this application in the Bay of Fundy, the Einstein-Brown bedload equation (Brown 1950) was used to compute the bedload transport rate. SEDTRANS computes the near-bed velocity profiles based on the combined-flow bottom boundary layer theory of Grant and Madsen (1986) and the suspended sediment concentration profiles using the Rouse method (Rouse, 1937). The suspended load transport rate was obtained from the vertical integration of the modelled velocity and suspended sediment concentration profiles. The bedload and suspended load transport rates were then vectorially added to derive the total sediment transport rate. Comparisons of model-predicted sediment transport rate and direction to limited measured suspended load transport (Amos and Joice 1977) and to predictions by a quasi-calibrated sediment transport model (Wu et al. 2011a) in the Sediment Transport section will further demonstrate that the sediment transport model used in this study has performed reasonably well. Given the focus of this study on the broader Bay of Fundy region, the results of the present study do not address the mobilization of cohesive sediments within intertidal flats and channels of the upper Bay (e.g. Mulligan et al. 2013; Tao et al. 2014).

\section{Results}




\section{Tidal and circulation currents}

RMS tidal current speed and maximum tidal current speed are shown in Figs. 3a and 3b respectively. Strong tidal currents occur over most part of the Bay of Fundy, with tidal current speed generally $>0.5 \mathrm{~m} \mathrm{~s}^{-1}$. The strongest tidal current occurs in the Minas Passage area where RMS tidal currents are greater than $1.4 \mathrm{~m} \mathrm{~s}^{-1}$ with maximum values of $2.4 \mathrm{~m} \mathrm{~s}^{-1}$. Strong tidal currents also occur in Minas Basin where the peak RMS tidal current reaches $>1 \mathrm{~m} \mathrm{~s}^{-1}$. Moderately strong tidal currents, $\sim 1 \mathrm{~m} \mathrm{~s}^{-1}$, are found in Chignecto Bay, in the central part of the Bay, in patches to the NW and SE of Grand Manan Island, and at the tip of Brier Island. Low tidal currents $\left(<0.5 \mathrm{~m} \mathrm{~s}^{-1}\right)$ mainly occur in the basin north of Grand Manan Island, in shallow waters of coastal bays and estuaries (e.g. Passamoquoddy Bay, Saint John Harbour, Saint Mary's Bay), and in the Gulf of Maine. The maximum tidal current reaches the extreme values of $>5 \mathrm{~m}$ $\mathrm{s}^{-1}$ in Minas Passage and is also strong $\left(\sim 2 \mathrm{~m} \mathrm{~s}^{-1}\right)$ in Minas Basin and in the narrows around Grand Manan Island (Fig. 3b). In contrast, circulation currents (Fig. 3c) are generally less than $0.3 \mathrm{~m} \mathrm{~s}^{-1}$ except in Minas Channel-Minas Basin area where background currents can range up to $1 \mathrm{~m} \mathrm{~s}^{-1}$.

\section{Waves}

The effect of waves generally decreases from southwest to northeast in the Bay of Fundy. Mean significant wave height (Fig. 4a) is the greatest in the outer Bay and Gulf of Maine (1 - 1.6 $\mathrm{m}$ ), decreases to $1.0-0.5 \mathrm{~m}$ in the mid-Bay, and is reduced further to $<0.5 \mathrm{~m}$ in the upper Bay. Wave periods reach $6 \mathrm{~s}$ in the outer Bay, decrease to $4-5 \mathrm{~s}$ in the mid-Bay and are less than $4 \mathrm{~s}$ in the upper Bay (Fig. 4b). Maximum significant wave heights can reach 5-6 $\mathrm{m}$ in the outer Bay and are generally less than $4 \mathrm{~m}$ in the mid-Bay and upper Bay (Fig. 4c).

\section{Seabed shear stress and sediment mobilization}

Seabed forcing or seabed shear stress $\tau$ can be represented by the shear velocity $\mathrm{u} *$ through 
the relationship of $\tau=\rho u_{*}{ }^{2}$, where $\rho$ is water density. The magnitude of tidal current shear velocity and sediment mobilization frequency (SMF) by tides is shown respectively in Figures $5 \mathrm{a}$ and $5 \mathrm{~b}$. Mean tidal current shear velocity is generally $>2 \mathrm{~cm} \mathrm{~s}^{-1}$ in the Bay of Fundy. The strongest tidal current shear velocity occurs in the Minas Passage area and reaches about $10 \mathrm{~cm} \mathrm{~s}^{-}$ ${ }^{1}$. Strong tidal current shear velocity up to $4-5 \mathrm{~cm} \mathrm{~s}^{-1}$ also occurs in Minas Basin, in the central Bay, and in the narrows around Grand Manan Island. Low tidal current shear velocity values of $<2 \mathrm{~cm} \mathrm{~s}^{-1}$ mainly occur in the basin north of Grand Manan Island, in coastal bays and estuaries, and in the Gulf of Maine. In comparison, wave shear velocity is predominantly less than $0.5 \mathrm{~cm}$ $\mathrm{s}^{-1}$ in the Bay of Fundy (Fig. 6a). Stronger wave shear, with values up to $4 \mathrm{~cm} \mathrm{~s}^{-1}$, only occurs in shallow waters of coastal bays and estuaries, and to the south and east of Grand Manan Island.

In correlation with the tidal and wave shear velocities, tidal current is the dominant process in mobilizing sediment in the Bay of Fundy. The sediment mobilization frequency (SMF) by tidal current alone is greater than $30 \%$ of the time over most of the Bay and reaches $100 \%$ in several areas (Fig. 5b). Tidal sediment mobilization frequency is less than $10 \%$ only in patches in the central Bay, in the outer Bay and in coastal bays and estuaries. The blank areas roughly in the centers of these patches indicate non-mobilization by tidal current. Waves only cause sediment mobilization in shallow coastal waters and in an area to the southeast of Grand Manan Island where SMF reaches up to $30 \%$ of the time (Fig. $6 \mathrm{~b}$ ).

Currents and waves interact non-linearly in the bottom boundary layer to produce enhanced combined-flow shear velocity (e.g. Grant and Madsen 1986). Figure 7a displays the combined shear velocity due to waves and the total current given by SEDTRANS. Wave and current interactions moderately enhance the seabed shear stress. This is particularly important in the shallow waters of coastal bays and estuaries, e.g. Passamoquoddy Bay, Saint John Harbour, and Saint Mary's Bay (see locations in Fig. 3a). In these areas, tidal currents alone cause low shear velocity values of $\sim 0.5 \mathrm{~cm} \mathrm{~s}^{-1}$ (Fig. 5a) but the combined-flow shear velocity reaches up to $2 \mathrm{~cm}$ $\mathrm{s}^{-1}$. As a result of this enhanced seabed forcing, wave and current interactions moderately enhance sediment mobilization in these coastal areas where the sediment mobilization frequency 
is increased from $<2 \%$ (Fig. $5 b$ ) to $>10 \%$ of the time (Fig. $7 b$ ).

\section{Sediment transport predictions}

\section{Spring tidal currents}

Tidal currents and sediment transport rates were modelled for the spring tide conditions which cause strongest currents and sediment transport. Tidal currents are $20 \%$ less for the average tide and 40\% less for the neap tide. For the spring peak flood (Fig. 8a), tidal currents are predominantly to the northeast (top of the Bay) but are to the northwest and then north at the mouth of the Bay. Maximum current speed up to $5 \mathrm{~m} \mathrm{~s}^{-1}$ occurs at Minas Passage by bathymetric constriction. Very strong currents up to $2-3 \mathrm{~m} \mathrm{~s}^{-1}$ are found in Minas Channel and Minas Basin. Strong currents up to $2 \mathrm{~m} \mathrm{~s}^{-1}$ also occur in Chignecto Bay, the upper mid-Bay and the narrows around Grand Manan Island. Tidal flow patterns at the peak ebb (Fig. 8b) are similar to that at peak flood. Only the directions are reversed: ebb currents are to southwest in the middle and upper Bay, and turn to south and southeast in the lower Bay and at the mouth of the Bay.

The net sediment transport in a tidally-dominated environment typically depends on the scale and direction of the tidal residual flow. The tidal currents predicted over two tidal cycles during spring tides (September 9-10 2009) were averaged to obtain the residual tidal currents under spring-tide conditions (Fig. 9a, b) which reveal complex patterns. The highest values, up to $1 \mathrm{~m}$ $\mathrm{s}^{-1}$, occur in the Minas Passage and Minas Channel area. Moderate residual tidal currents, up to $0.3 \mathrm{~m} \mathrm{~s}^{-1}$, are also found in Minas Basin, in Chignecto Bay, to the southeast of Grand Manan Island, and at the tip of Brier Island (See Figs. 1 and 9 for location names). Several prominent tidal eddies, particularly in the upper Bay, can be identified. The most striking one is the counterclockwise eddy to the west of Cape Split (Fig. 9a). The eddy occupies the entire Minas Channel with its center about $10 \mathrm{~km}$ from Cape Split. The maximum velocity reaches more than $1 \mathrm{~m} \mathrm{~s}^{-1}$. A smaller clockwise eddy with the same current strength is located in the Minas Passage just east of Cape Split. These paired clockwise and counter-clockwise eddies are believed to contribute to the genesis of sand and gravel banner banks off Cape Split (Shaw et al. 2012; Li et al. 2014). A 
large eddy system is identified south of Cape D'Or and Cape Chignecto (Fig. 9a). This system consists of a well-developed clockwise eddy west of Cape D'Or and a less developed clockwise eddy that is located west of Cape Chignecto and extends to the mouth of Chignecto Bay. Another well-developed clockwise eddy is located in western Minas Basin and extends over the Southern Bight. Further east, a series of four alternating clockwise and counter-clockwise eddies are recognized over eastern Minas Basin and Cobequid Bay. Another series of 3 to 4 alternating tidal eddies can be recognized in the central and upper Chignecto Bay. Though less developed, a counter-clockwise eddy and a clockwise eddy can be respectively recognized east of Grand Manan Island and at the tip of Brier Island (Fig. 9b).

\section{Sediment transport}

Model-predicted bedload flux at peak flood is compared with the suspended load flux in Figure 10. The total-load sediment transport flux for peak spring tide and the net sediment transport flux averaged over two flood-ebb cycles are shown in Fig. 11 and Fig. 12 respectively (See Figs. 1 and 9 for location names). The sediment transport predictions of this study are compared to limited field data (Amos and Joice, 1977) and the simulations of a quasi-calibrated model (Wu et al. 2011a) to evaluate the performance of the sediment transport models used in the present study. Amos and Joice (1977) measured suspended sediment transport flux over 1-4 tidal cycles at 14 locations in Minas Basin in summer 1975 and in summer and fall 1976 respectively. Through integrating measured velocity and suspended sediment concentration profiles, Amos and Joice (1977) showed that the suspended sediment flux (SSF) reaches 0.5 to $0.6 \mathrm{~kg} \mathrm{~m}^{-1} \mathrm{~s}^{-1}$ for peak tidal conditions at the eastern outlet of Minas Passage. By comparison, the modelled SSF of this study is up to $0.3 \mathrm{~kg} \mathrm{~m}^{-1} \mathrm{~s}^{-1}$ at this location (Fig. 10b) which is in reasonable agreement with the measured values. Wu et al. (2011a) recently modelled sediment transport for the upper Bay of Fundy. The model was partially verified by comparing the model results with the observed seabed erosion and deposition patterns and with limited measured net suspended load flux. Wu et al. (2011a) estimate that the net total load flux in Minas Passage is eastward and is up to $1 \mathrm{~kg} \mathrm{~m}^{-1} \mathrm{~s}^{-1}$ (Fig. 16 of Wu et al.). Similar magnitude and direction of net total load flux are also predicted by this study (Fig. 12a). In Minas Channel, the net total load 
flux by Wu et al. shows a counter-clockwise structure (their Fig. 16). This feature is also well modelled by this study (Fig. 12a). The above comparisons arguably demonstrate that the sediment transport patterns simulated in this study are in reasonable agreement with limited measured data and the predictions from the quasi-calibrated model.

The comparison between the bedload and suspended load flux at peak flood (Fig. 10) shows that bedload transport nearly occurs over the entire Bay and its peak values reach $\sim 5 \mathrm{~kg} \mathrm{~m}^{-1} \mathrm{~s}^{-1}$. Suspended load transport is only found for restricted areas (e.g. in Minas Basin and to the northeast of Grand Manan Island) and its magnitude is also generally 1 order of magnitude smaller than the bedload flux. Therefore bedload transport is dominant in the Bay of Fundy.

The total load sediment transport flux (Fig. 11) is well correlated with the tidal current patterns shown in Fig. 8. Sediment transport is to the northeast during flood and to the southwest during ebb. The highest flux occurs in Minas Passage and reaches $\sim 5 \mathrm{~kg} \mathrm{~m}^{-1} \mathrm{~s}^{-1}$. Strong transport rates of 1 to $2 \mathrm{~kg} \mathrm{~m}^{-1} \mathrm{~s}^{-1}$ are also predicted for Chignecto Bay, the mid-Bay and the narrows around Grand Manan Island. Low transport rates $\left(<0.1 \mathrm{~kg} \mathrm{~m}^{-1} \mathrm{~s}^{-1}\right)$ occur in the lower Bay and in a patch in the lower mid-Bay off Digby. The net total load transport flux averaged over two spring tidal cycles (Figure 12) shows that the highest values reach 1 to $2 \mathrm{~kg} \mathrm{~m}^{-1} \mathrm{~s}^{-1}$ and occur in Minas Channel, Minas Passage and western Minas Basin. Moderately strong net transport of $\sim 0.1 \mathrm{~kg} \mathrm{~m}^{-1} \mathrm{~s}^{-1}$ is found in Minas Basin, in Chignecto Bay, over patches in the middle and upper Bay, and in the narrows around Grand Manan Island. Low net transport flux, $<0.01 \mathrm{~kg} \mathrm{~m}^{-1} \mathrm{~s}^{-1}$, occurs in a patch in the lower mid-Bay, in the lower Bay, and in the Gulf of Maine.

Several spatial patterns of net transport direction can be recognized. Firstly, the net sediment transport is dominantly to the northeast in the middle and upper Bay of Fundy. In the lower Bay and Gulf of Maine, net transport is to the north and northeast, into the Bay, on the Nova Scotia side and to the southwest, out of the Bay, on the US side (Fig. 12b). In the upper Bay (Fig. 12a), the net transport is generally to the northeast (i.e. towards the top of the Bay). But a narrow band of reversed net transport to the southwest can be found just offshore on the Nova Scotia side. 
Secondly, the net transport flux in Minas Channel and Minas Basin displays several gyre-like structures that can be correlated with the residual tidal current patterns shown in Figure 9. A large, well developed counter-clockwise gyre occurs in Minas Channel to the west of Cape Split. A smaller but also well-developed clockwise gyre is found in Minas Passage east of Cape Split. A clockwise gyre is found in western Minas Basin which drives the net sediment transport southward in Southern Bight. Over central and eastern Minas Basin, the net sediment transport is eastward on the northern side and westward on the southern side except along the coast where the net transport is to the east. Alternating clockwise and counter-clockwise net transport gyres can be recognized in Cobequid Bay, though they are not as well developed as the residual flow eddies shown in Fig. 9a. A well-developed clockwise gyre of net transport is found west of Cape D'Or and this is well correlated with the clockwise eddy of residual flow shown in Figure 9a. The net sediment transport is dominantly to the northeast in Chignecto Bay, and no welldeveloped gyres are distinguished. In the lower Bay (Fig. 12b), a pair of clockwise and counterclockwise gyres of net sediment transport is found to the southeast of Grand Manan Island. A less-developed counter-clockwise gyre is also found at the tip of Brier Island. Lastly, prominent divergences of sediment transport are found at several locations. One is at Cape Split where the net transport is to the west in Minas Channel but to the east in Minas Passage (Fig. 12a). This was also recognized in the modelling study by Wu et al. (2011a). Another is in the narrows west of Grand Manan Island where the net transport is to the northeast on the northern side of the divergence, and to the southwest on the southern side of the divergence (Fig. 12b).

\section{Discussion}

\section{Disturbance type classification}

Evaluating the time percentages by which the bedload transport threshold is exceeded by tide, waves, and circulation current allows an assessment of the relative spatial importance of these processes in mobilising bottom sediments in the Bay of Fundy. A classification scheme used for the Australian continental shelf (Porter-Smith et al. 2004) was modified for the 
disturbance type classification in the Bay of Fundy. "Tide-dominated" disturbance type applies to locations where the time percentage of mobilisation by tidal current is greater than two times that by either waves or circulation current. "Wave-dominated" type and "circulation-dominated" type are similarly defined. Locations that do not fall into any of the three types defined above are classified as "mixed-disturbance" type. The regionalisation of seabed disturbance type (Fig. 13a) reveals that sediment mobilization in the Bay of Fundy is predominantly by the strong tidal current. Wave-dominated disturbance is restricted in coastal waters and around Grand Manan Island. Mixed disturbance occurs as narrow transition zones between tide-dominated and wavedominated types. Tidal current and circulation current each cause mobilization in Minas Channel and Minas Passage, $100 \%$ of the time. Because maximum tidal current is several times stronger than the circulation current in these areas, they are classified as tide dominated type.

The study by Porter-Smith et al. (2004) found that sediments on the Australian shelves are nearly equally mobilized by waves $(\sim 31 \%$ of the shelf area) and tides ( $\sim 41 \%$ of the shelf area). Sediment mobilization by waves, however, is much less significant in the Bay of Fundy (Fig. 13a). This contrast is largely attributed to the fact "the tide rules in the Bay of Fundy" as wave shear velocity is typically 4 times less than tidal current shear velocity (Figs. 5 and 6).

\section{Seabed disturbance and sediment mobility indices}

The combined wave-current shear velocity of Fig. 7a shows the magnitude of seabed forcing but reveals nothing about the occurrence frequency of the stress values. On the contrary, the sediment mobilization frequency map of Fig. $7 \mathrm{~b}$ represents how often bottom sediment gets mobilized and provides no information about how strong the mobilisation is. A seabed disturbance index and a sediment mobility index are proposed to quantify seabed forcing and sediment mobilisation incorporating both the magnitude and the frequency of these parameters (Li et al. 2009b). The Seabed Disturbance Index (SDI) is defined similarly to that of Hemer (2006): the maximum value of the product $\left(\tau_{\mathrm{cws}}\right)^{1.5} \mathrm{P}$ where $\tau_{\mathrm{cws}}$ is the combined wave-current

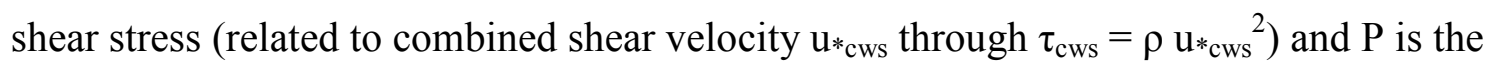


probability distribution of $\tau_{\mathrm{cws}}$. Thus SDI quantifies the force exerted on the seabed by the combined waves and currents considering both the magnitude and frequency of the bed shear stress regardless whether sediment mobilization occurs or not. The Sediment Mobility Index (SMI) is calculated as $\left(\tau_{\mathrm{cws}} / \tau_{\mathrm{cr}}\right) \mathrm{x}$ threshold exceedance $\%$ where threshold exceedance $\%$ is the percent of time the critical shear stress for sediment motion $\tau_{\mathrm{cr}}$ being exceeded by $\tau_{\mathrm{cws}}$, and $\tau_{\mathrm{cws}} / \tau_{\mathrm{cr}}$ is the average ratio for times when $\tau_{\mathrm{cr}}$ is exceeded. Thus SMI is a non-dimensional index that indicates the level of sediment mobility integrating both the magnitude and frequency of the sediment mobilisation process (Li et al. 2009b).

The Seabed Disturbance Index and Sediment Mobility Index so derived for the Bay of Fundy are shown in Figs. 13b and 13c respectively. The strongest disturbance, with a maximum value of 2, occurs in the Minas Passage and Minas Channel area (Fig. 13b). Strong disturbances with values of 1 to 1.2 are predicted for the upper mid-Bay, around Grand Manan Island, and over the approach to the Bay off western Nova Scotia. Low disturbances with values $<0.7$ are found in the basin north of Grand Manan Island, in coastal bays and estuaries, and at the mouth of the Bay. The highest sediment mobility, with values up to 2, occurs in the Minas Channel and Minas Passage area, extending into Minas Basin due to the finer grain size in the basin (Fig. 13c). A similar level of mobility also occurs in the narrows around Grand Manan Island and over the approach to the Bay off western Nova Scotia. Moderately high sediment mobility levels, with SMI values 1.2 - 1.6, are predicted in the upper mid-Bay and in Chignecto Bay. Low mobility of $<0.7$ mainly occurs in the lower mid-Bay and at the mouth of the Bay. Patches of zero mobility are found in the Gulf of Maine, in the lower mid-Bay, and in coastal bays and estuaries.

Patterns of sediment mobility shown in Fig. 13c are largely controlled by seabed forcing represented by combined wave-current shear velocity, $\mathrm{u}_{*_{\mathrm{cws}}}$ (Fig. 7a) and bottom sediment grain size shown in Figure 2b. The broader Minas Basin area, including Minas Channel, Minas Passage and Minas Basin (Fig. 1), displays the highest seabed forcing, over finer grain size (dominantly coarse sand). Therefore the highest sediment mobility occurs in this area (Fig. 13c). In the lower Bay of Fundy and Gulf of Maine, the grain size spreads over a wide range $(0.01 \mathrm{~mm}$ 
to $10 \mathrm{~mm}$; Fig. 2b). However, this vast area is dominated by low seabed forcing $\left(\mathrm{u} *{ }^{\mathrm{cws}}<2 \mathrm{~cm} \mathrm{~s}^{-1}\right)$ which causes low and sometimes zero sediment mobility in this area. Combined shear velocity is uniformly high (4-5 $\left.\mathrm{cm} \mathrm{s}^{-1}\right)$ in the central Bay of Fundy (Fig. 7a). However, bottom sediments of the lower central Bay are much coarser than that over the upper central Bay (Fig. 2b). This difference in substrate types ultimately determines that sediment mobility is moderately high in the upper central Bay while low sediment mobility occurs in the lower central Bay (Fig. 13c).

Hemer (2006) has computed the Seabed Disturbance Index for the entire Australian shelf for an 8-year period. The mean SDI for areas with highest seabed disturbance on the Australian shelf is $\sim 1.3$. In contrast, the maximum SDI values are up to 1.7 to 2 in the Bay of Fundy. While this difference suggests that the seabed disturbance level in the Bay of Fundy is generally stronger than that on the Australian shelf, at least the ranges of SDI values are comparable, possibly implying that the SDI scheme used in these studies could potentially be used as a universal index for absolute quantification of seabed disturbance in other continental shelf regions.

\section{Comparisons of tidal and sediment transport predictions with previous studies}

Previous tidal modeling studies in the Bay of Fundy include modeling of the elevation amplitude and phase of M2 (Greenberg 1979), simulations of the residual barotropic circulation generated by tides and steady winds (Greenberg 1983), and the application and verification of a tidal model focused on the sea level for the upper Bay of Fundy (Dupont et al. 2005). A systematic description of the tidal current magnitude and spatial variation for the entire Bay of Fundy was not given in these studies. Only Greenberg (1984) cited the magnitude of the maximum tidal currents at various places in the Bay of Fundy. This study presents the comprehensive patterns of both the RMS and maximum tidal currents for the Bay of Fundy (Figs. 3 and 8) based on a finite-element model containing 10 tidal constituents. The strongest tidal currents are up to $5 \mathrm{~m} \mathrm{~s}^{-1}$ and occur at Minas Passage by bathymetric constriction. Very strong currents, up to 2-3 $\mathrm{m} \mathrm{s}^{-1}$, are also found in Minas Channel, Minas Basin, Chignecto Bay, and the narrows around Grand Manan Island. The direction of the currents is predominantly to 
the northeast at peak flood and to the southwest at peak ebb, except the coastline-hugging rotation over the approach to the Bay off Nova Scotia (Fig. 8).

The modelling of the residual tidal currents in the Bay of Fundy by Greenberg (1983) identified four eddies around Minas Passage. The strong counter-clockwise eddy in Minas Channel has currents of order $0.5 \mathrm{~m} \mathrm{~s}^{-1}$ while the second major eddy in western Minas Basin is clockwise and shows residual currents of 0.1 to $0.2 \mathrm{~m} \mathrm{~s}^{-1}$. More detailed and improved knowledge on residual tidal currents are achieved in this study. The magnitude of residual tidal currents is stronger than that recognized in previous works. The highest values, up to $1 \mathrm{~m} \mathrm{~s}^{-1}$, occur in the Minas Passage and Minas Channel area (Fig. 9). Strong residual tidal currents up to $0.7 \mathrm{~m} \mathrm{~s}^{-1}$ are also found in western Minas Basin, west of Cape D’Or and in western Cobequid Bay. Similar magnitudes of residual tidal currents have also been predicted for the upper Bay by Wu et al. (2011a). The spatial patterns of the residual tidal currents are also much more complex than previously thought. This study has confirmed the four prominent paired clockwise and counter-clockwise eddies in Minas Channel-Minas Passage area that were described in previous studies (Greenberg 1983; Wu et al. 2011a). However, several additional tidal eddy systems have also been found (see Fig. 9 and the "Spring tidal currents" section). Modelling results from both Greenberg (1983) and this study indicate that the barotropic residual tidal currents in the lower Bay are weak (typically $<0.03 \mathrm{~m} \mathrm{~s}^{-1}$ ) and do not show the presence of the counter-clockwise eddy as suggested by the data analysis of Godin (1968). These findings on the residual tidal currents have important implications to our understanding of the net sediment transport in the Bay of Fundy.

This study is the first that attempts to model seabed shear stresses and sediment transport patterns for the entire Bay of Fundy using integrated tidal, wave, ocean current and sediment transport models. Previous measurements and model predictions of sediment transport in the Bay of Fundy are very sparse and geographically limited for comparisons. Wu et al. (2011a) provided quasi-predictions of sediment transport in the upper Bay of Fundy. They estimated maximum bedload transport of $\sim 2.0 \mathrm{~kg} \mathrm{~m}^{-1} \mathrm{~s}^{-1}$ in Minas Passage and much lower values of $0.1-0.5 \mathrm{~kg} \mathrm{~m}^{-1}$ 
$\mathrm{s}^{-1}$ in other areas of the upper Bay of Fundy. This study predicts maximum bedload transport of $\sim 5.0 \mathrm{~kg} \mathrm{~m}^{-1} \mathrm{~s}^{-1}$ in Minas Passage and values of $\sim 1 \mathrm{~kg} \mathrm{~m}^{-1} \mathrm{~s}^{-1}$ in other areas of the upper Bay of Fundy (Fig. 10a). The higher bedload fluxes derived by this study are likely due to finer grain size (medium to coarse sands) used in this study. The differences could also result from the fact that $\mathrm{Wu}$ et al. (2011) used a three dimensional model over variable bottom roughness and that their bottom shear stress and bedload sediment transport were derived from the bottom currents.

Suspended load transport was partly modelled for the upper Bay by Wu et al. (2011a) using model-predicted velocity and remote-sensing measurements of surface sediment concentration, while the present study models suspended load transport for the entire Bay of Fundy through the integration of model-predicted velocity and suspended sediment concentration profiles. Amos and Joice (1977) estimated suspended load flux in the Minas Channel-Minas Basin area based on measured velocity and suspended sediment concentration profiles. The measured suspended load flux for peak tidal conditions at the eastern outlet of Minas Passage was 0.5 to $0.6 \mathrm{~kg} \mathrm{~m}^{-1} \mathrm{~s}^{-1}$. These are in good agreement with model-predicted maximum suspended load flux ( $\sim 0.3$ to 0.5 $\mathrm{kg} \mathrm{m}^{-1} \mathrm{~s}^{-1}$ ) from this study (Fig. 10b) and from Wu et al. (2011a; Fig. 15), providing confidence in suspended load predictions by these studies. For other parts of the Minas Channel - Minas Basin area, Wu et al. (2011a) and the present study both show that the maximum suspended load transport of $\sim 2.0 \mathrm{~kg} \mathrm{~m}^{-1} \mathrm{~s}^{-1}$ occurs in Minas Passage and values in other areas are typically 0.01 to $0.5 \mathrm{~kg} \mathrm{~m}^{-1} \mathrm{~s}^{-1}$. The modelled net suspended load transport was also in fair agreement with the measurements by Amos and Joice (1977). For instance, the eastward net suspended flux of $0.05-0.06 \mathrm{~kg} \mathrm{~m}^{-1} \mathrm{~s}^{-1}$ and $0.08 \mathrm{~kg} \mathrm{~m}^{-1} \mathrm{~s}^{-1}$ were respectively measured at the eastern outlet of Minas Passage and in Cobequid Bay. The modelled net suspended load at these sites was also to the east, and the fluxes were $\sim 0.02$ and $\sim 0.04 \mathrm{~kg} \mathrm{~m}^{-1} \mathrm{~s}^{-1}$ respectively. The directions of measured net suspended load flux in southwestern Minas Basin and in Minas Channel are in qualitative agreement with the clockwise and counter-clockwise eddies in these areas, as predicted by the model (see Fig. 12b). However, the modelled net flux values are about one order of magnitude smaller. These differences are probably due to our poor knowledge of the distribution of the finefractions in the bottom sediments. 
For the total load transport, both $\mathrm{Wu}$ et al. (2011a) and the present study suggest a maximum value of $\sim 5 \mathrm{~kg} \mathrm{~m}^{-1} \mathrm{~s}^{-1}$ in Minas Passage (Fig. 11). For the magnitude and pattern of net total load transport, both $\mathrm{Wu}$ et al. (2011a) and the present study find that the maximum net total transport reaches $1-2 \mathrm{~kg} \mathrm{~m}^{-1} \mathrm{~s}^{-1}$ in Minas Passage (Fig. 12a), despite that the residual currents in Wu et al. were from 29 days model results and the present study uses spring-tide residual currents. The net total load flux from Wu et al. (2011a) only reaches 0.1 to $0.2 \mathrm{~kg} \mathrm{~m}^{-1} \mathrm{~s}^{-1}$ in Minas Channel, Minas Basin and Cobequid Bay while much higher fluxes $\left(0.5\right.$ to $\left.1 \mathrm{~kg} \mathrm{~m}^{-1} \mathrm{~s}^{-1}\right)$ are given by this study. These higher values are likely attributed to the significantly higher bedload transport predicted by the present study, and to the use of bottom currents by $\mathrm{Wu}$ et al. in computing sediment transport. Modelling results from both Wu et al. (2011a) and the present study establish that net total load transport is largely eastward in Minas Passage and that a counter-clockwise gyre occurs in Minas Channel and a clockwise gyre is present in western Minas Basin (Fig. 12a). Wu et al. (2011a) finds a simple pattern of eastward net sediment transport in Cobequid Bay. The present study further shows that alternating clockwise and counter-clockwise gyres of net transport are superimposed on the general trend of eastward net transport in Cobequid Bay (Fig. $12 \mathrm{a})$.

\section{Applications to regional substrate distribution and patterns of erosion and deposition}

Backscatter strength, collected from the multibeam sonar mapping surveys (Parrott et al. 2010; Todd et al. 2014), displays the distribution of various substrate types in the Bay of Fundy (Fig. 14). The regional substrate distribution is well correlated with tidal current strength (Fig. 3a) and net sediment transport pattern (Fig. 12). Strong tidal currents occur in Minas Channel Minas Passage area and in the narrows around Grand Manan Island. The strong tidal current forcing causes erosion of the seabed and hence occurrences of the exposed bedrock or the winnowed gravelly lag in till deposits in these areas (Todd et al. 2014; Shaw et al. 2014). In contrary, the tidal current is very low in the basin northeast of Grand Manan Island and the western part of the lower mid-Bay. This low tidal current forcing favors accumulation of finer sediments and results in the wide distribution of mud or sandy mud in this region. 
Strong tidal currents actively erode the seabed in Minas Channel and Minas Passage and cause high sediment transport in this area (Figs. $3 \mathrm{a}$ and 12). An estimated volume of $\sim 5 \mathrm{~km}^{3}$ has been eroded away from the Minas Channel - Minas Passage area since late Holocene (Shaw et al. 2012). This area is thus a major sediment source for the Bay of Fundy. The mud fraction of the eroded material likely has been dispersed throughout the Bay in suspension. The sand and gravel fractions, however, have moved as bedload transport. The modelled sediment transport shows an overall pattern of net transport to the northeast in the Bay of Fundy (Fig. 12) which confines sandy sediment in the upper Bay. This, combined with the Minas Channel - Minas Passage as the sediment source area, explains why the distribution of sandy sediment mostly occurs in the upper Bay and upper mid-Bay, generally restricted to northeast of a line drawn between Digby and Saint John (Fig. 14). The restriction of sandy sediment within the upper Bay and active movement of this sandy sediment under moderately strong tidal currents (Fig. 3a) also control the outcome that major bedforms and bedform fields are concentrated in the upper and upper mid-Bay (22 sites recognized; Todd et al. 2014). Only four smaller bedform sites are recognized in the lower Bay, and these are probably flow-parallel morphological features in muddy sediments. The confinement of sandy sediment in the upper and upper-mid Bay limits the availability of this sediment to the lower mid-Bay and the lower Bay, and contributes to the dominance of gravelly lag deposits in these parts of the Bay (Fig. 14).

Analysis of the sub-bottom profile data of Amos and Joice (1977) suggests that the central Minas Basin is a deposition centre with a maximum thickness of $8 \mathrm{~m}$ of post-Pleistocene sediment. Another area of sediment accumulation is in the north-eastern part of the Southern Bight with $\sim 6 \mathrm{~m}$ sediment thickness. These deposition centers are well supported by our modelling results. The deposition center at the central Minas Basin is attributed to the decrease of the net total load flux (Fig. 12a) from the western to the central Minas Basin (Fig. 12a) and a convergence of net total load transport towards the centre of the Basin which was also predicted by Wu et al. (2011a). The second depositional centre coincides with the centre of the clockwise 
gyre of net total load flux at the western Minas Basin (Fig. 12a) and the zone of decreasing net transport rate associated with the eastern branch of this clockwise gyre.

\section{Concluding remarks}

A systematic description of the tidal flow pattern for the entire Bay of Fundy was previously unavailable. The present study is the first to present a comprehensive description of the magnitude and spatial variation of tidal currents for the entire Bay of Fundy. Previous reviews have identified the critical need for integrated hydrodynamics and sediment transport models that can predict sediment movement for the entire Bay of Fundy (Fader 1997; Percy et al. 1997). Limited previous modelling studies of sediment transport in the Bay of Fundy only considered tidal flows and were restricted to local areas in the upper Bay (Greenberg and Amos 1983; Wu et al. 2011a). The results of this study have filled this knowledge gap by providing modelling results of seabed shear stresses and sediment transport patterns for the broader Bay of Fundy, through integrated applications of tidal, wave, ocean current and sediment transport models. The present study is also the first exploration to quantify the seabed disturbance that goes beyond the tides, and includes waves and wind-driven currents of storms.

Strong tidal currents occur over most part of the Bay of Fundy. The RMS tidal current is the highest in the upper Bay $\left(>1.4 \mathrm{~m} \mathrm{~s}^{-1}\right)$, reduces to moderate values in the central Bay $(0.5-0.8 \mathrm{~m}$ $\left.\mathrm{s}^{-1}\right)$ and decreases further in the outer Bay $\left(0.2-0.5 \mathrm{~m} \mathrm{~s}^{-1}\right)$. The maximum tidal current reaches the extreme values of $>5 \mathrm{~m} \mathrm{~s}^{-1}$ in Minas Passage. Mean significant wave heights range from 0.5 to $1.3 \mathrm{~m}$. Ocean circulation currents are generally less than $0.3 \mathrm{~m} \mathrm{~s}^{-1}$. Seabed shear in the Bay of Fundy is dominated by tides. Mean tidal current shear velocity often reaches 4 to $5 \mathrm{~cm} \mathrm{~s}^{-1}$ and maximum values up to $10 \mathrm{~cm} \mathrm{~s}^{-1}$ occur in the Minas Passage area. Wave shear velocity typically is less than $0.5 \mathrm{~cm} \mathrm{~s}^{-1}$. The present study also establishes that the magnitude of residual tidal currents is stronger and their patterns are more complex than recognized in previous works.

Total-load transport using observed grain size data was modelled for the first time for the 
entire Bay of Fundy. The total-load sediment transport for spring tide is to the northeast during flood and to the southwest during ebb. The highest flux of $\sim 5 \mathrm{~kg} \mathrm{~m}^{-1} \mathrm{~s}^{-1}$ occurs in Minas Passage and strong transport rates of $1-2 \mathrm{~kg} \mathrm{~m}^{-1} \mathrm{~s}^{-1}$ are found in the mid-Bay and around Grand Manan Island. The net total load transport flux is the highest in Minas Channel, Minas Passage and western Minas Basin and reaches 1 to $2 \mathrm{~kg} \mathrm{~m}^{-1} \mathrm{~s}^{-1}$. Moderately strong net transport of $\sim 0.1 \mathrm{~kg} \mathrm{~m}^{-1}$ $\mathrm{s}^{-1}$ is found in patches in the middle and upper Bay and in the narrows around Grand Manan Island. Net sediment transport is dominantly to the northeast in the middle and upper Bay of Fundy. In the lower Bay, the net transport is to the northeast on the Nova Scotia side and to the southwest on the US side. In good correlations with the patterns of the residual tidal flows, prominent eddies of net transport flux are found around headlands and in bathymetric restrictions throughout the Bay of Fundy.

New and improved knowledge of flow and sediment transport patterns for the broader Bay of Fundy enable better understanding of substrate type distribution and patterns of erosion and deposition in the study region. The occurrence of the exposed bedrock in the Minas Channel Minas Passage area and the gravelly deposits in the narrows around Grand Manan Island, correlate well with the strong tidal currents in these areas that cause active erosion of the seabed and winnowing of bottom sediments. The low tidal current in the basin to the northeast of Grand Manan Island favors accumulation of finer sediments and results in the wide distribution of mud in this region. The eroding Minas Channel - Minas Passage area acts as one of the main sediment sources in the Bay of Fundy. This, together with the overall pattern of net transport to the northeast, confines the sandy sediment in the upper and upper mid-Bay, where moderately strong tidal currents actively transport this sandy sediment to cause major bedform fields to be concentrated in this area. The deposition centers and sediment accumulation in Minas Basin are well supported by the modeled spatial gradients and convergence of net sediment transport in the Basin.

Seabed shear stress and time percentage of sediment mobilization typically used to describe seabed disturbance and sediment mobility on continental shelves are inadequate to quantify both 
the frequency and magnitude of these processes. This study together with the work of Hemer (2006) have developed the innovative Sediment Disturbance Index and Sediment Mobility Index which provide absolute quantification of seabed disturbance and sediment mobility integrating both the magnitude and frequency of these parameters. Sediment mobilization in the Bay of Fundy is predominantly by tidal current and wave-dominated disturbance is only important in coastal waters. Seabed disturbance and sediment mobility are the highest at Minas Passage, moderately strong in the upper mid-Bay and at the narrows of Grand Manan Island, and weak in the lower Bay. The comparable ranges of SDI values in the Bay of Fundy and on the Australian shelf imply that the SDI scheme developed in these studies could potentially be used as a universal index for absolute quantification of seabed disturbance on continental shelves and hence have significant impact on the bio-regionalization in many continental shelf regions of the world.

\section{Acknowledgments}

We would like to thank Brian Todd and John Shaw for providing the backscatter data and its interpretation. We are thankful to Bash Toulany, Jason Chaffey, and Yongsheng Wu for contributing to wave, tidal current and ocean current modelling. We appreciate the useful comments from two anonymous journal reviewers. This research was supported by Geological Survey of Canada Offshore Geoscience Program, GSC Environmental Geoscience Program, and the Clean Energy Fund of Government of Canada. This is Earth Sciences Sector contribution number 20130082. 


\section{References}

Amos, C.L. 1987. Fine-grained sediment transport in Chignecto Bay, Bay of Fundy, Canada. Continental Shelf Research, 7: 1295-1300.

Amos, C.L., and Joice, G.H.E. 1977. The sediment budget of the Minas Basin, Bay of Fundy, N.S. Bedford Institute of Oceanography Data Series BI-D-77-3, 411 pp.

Bastos, A.C., Paphitis, D., Collins, M.B. 2004. Short-term dynamics and maintenance processes of headland-associated sandbanks: Shambles Bank, English Channel, UK. Estuarine, Coastal and Shelf Science, 59: 33-47.

Brown, C.B. 1950. Sediment transportation. In: Engineering Hydraulics, Edited by Rouse, H., New York, John Wiley and Sons, 796p

Butman, B., Noble, M.A., Folger, D.W. 1979. Long-term observations of bottom current and bottom sediment movement on the Mid-Atlantic continental shelf. Journal of Geophysical Research, 84(C3): 1187-1205.

Cacchione, D.A. and Drake, D.E. 1990. Shelf sediment transport: An overview with applications to the Northern California continental shelf. In The Sea, Vol.9, Edited by B. Le Mehaute and D.M. Hanes, Wiley-Interscience, pp. 729-773.

Davies, A.M., Xing, J. 2002. Processes influencing suspended sediment movement on the MalinHebrides shelf. Continental Shelf Research, 22: 2081-2113.

Dalrymple, R.W., Knight, R.J. and Larbiase, J.J. 1978. Bedforms and their hydraulic stability relationships in a tidal environment, Bay of Fundy, Canada. Nature, 275: 100-104.

Duffy, G.P., Hughes-Clarke, J.E., Parrott, R. 2004. Application of current measurement and time lapsed bathymetric multibeam surveying to investigation of a banner bank, Mispec Bay, New Brunswick, Canada. In Marine Sandwave Dynamics and River Dune Dynamics II, Edited by Hulscher, S.J.M.H., Garlan, T., Idier, D., International Workshop, University of Twente, Enschede, The Netherlands, pp. 72-78.

Dupont, F., Hannah, C.G. and Greenberg, D.A. 2005. Modelling the sea level in the upper Bay of Fundy. Atmosphere-Ocean, 43: 33-47.

Fader, G.B.J. 1997. Aggregate assessment and sediment transport. Chapter 2, section 2.2.2, In Bay of Fundy Issues: a scientific overview, Edited by Percy, J.A. Wells, P.G. and Evans, A.J.,Workshop Proceedings, Wolfville, Nova Scotia, Jan. 29 to Feb. 1, 1996. 
Godin, G. 1968. The 1965 current survey of the Bay of Fundy: A new analysis of the data and an interpretation of results. Manuscript Report Series, No.8, 97 pp., Marine Sciences Branch, Energy Mines and Resources, Ottawa.

Grant, W.D., and Madsen, O.S. 1986. The continental shelf bottom boundary layer. Annual Review of Fluid Mechanics 18: 265-305.

Greenberg, D.A. 1979. A numerical model investigation of tidal phenomena in the Bay of Fundy and Gulf of Maine. Marine Geodesy, 2: 161-187.

Greenberg, D.A. 1983. Modelling the mean barotropic circulation in the Bay of Fundy and Gulf of Maine. Journal of Physical Oceanography, 13: 886-904.

Greenberg, D.A. 1984. A review of the physical oceanography of the Bay of Fundy. In Update on the marine environmental consequences of tidal power development in the upper reaches of the Bay of Fundy, Edited by D.C. Gordon, Jr. and M. J. Dadswell, Canadian Technical Report of Fisheries and Aquatic Sciences 1256, p. 9-30.

Greenberg, D.A., and Amos, C.L. 1983. Suspended sediment transport and depositional modeling of the Bay of Fundy, Nova Scotia - a region of potential tidal power development. Canadian Journal of Fisheries and Aquatic Sciences, 40 (Suppl. 1): 20-34.

Harris, C.K., Wiberg, P.L. 2001. A two-dimensional, time-dependent model of suspended sediment transport and bed reworking for continental shelves. Computers and Geosciences, 27: $675-690$.

Harris, C. K., Sherwood, C. R., Signell, R.P., Bever, A.J., and Warner, J.C. 2008. Sediment dispersal in the northwestern Adriatic Sea. Journal of Geophysical Research, 113: C11S03, doi:10.1029/2006JC003868.

Hasegawa, D., Sheng, J., Greenberg, D.A. and Thompson, K.R. 2011. Far-field effects of tidal energy extraction in the Minas Passage on tidal circulation in the Bay of Fundy and Gulf of Maine using a nested-grid coastal circulation model. Ocean Dynamics, Doi 10.1007/s10236-0110481-9.

Hemer, M.A. 2006. The magnitude and frequency of combined flow bed shear stress as a measure of exposure on the Australian continental shelf. Continental Shelf Research, 26: 12581280 .

Holt, J.T., James, I.D. 1999. A simulation of the southern North Sea in comparison with measurements from the North Sea Project, Part 2: suspended particulate matter. Continental Shelf Research, 19: 1617-1642.

Jacques Whitford, 2008. Final Report, Background Report for the Fundy Tidal Energy Strategic 
Environmental Assessment. 291 pp.

Karsten, R.H., McMillan, J.M., Lickley, M.J. and Haynes, R.D. 2008. Assessment of tidal current energy in the Minas Passage, Bay of Fundy. Proceedings of the Institution of Mechanical Engineers, Part A: Journal of Power and Energy, 222: 493-507.

Li, M.Z. and Amos, C.L. 2001. SEDTRANS96: the upgraded and better calibrated sediment transport model for continental shelves. Computers and Geosciences, 27: 619-645.

Li, M.Z., Amos, C.L., and Heffler, D.E. 1997. Boundary layer dynamics and sediment transport under storm and non-storm conditions on the Scotian Shelf. Marine Geology, 141: 157-181.

Li, M.Z., Parrott, D.R., and Yang, Z. 2009a. Sediment stability and dispersion at the Black Point offshore disposal site, Saint John Harbour, New Brunswick, Canada. Journal of Coastal Research, 25: 1025-1040.

Li, M.Z., Zou, Q., Hannah, C., Perrie, W., Prescott, R. and Toulany, B. 2009b. Numerical Modelling of Seabed Disturbance and Sediment Mobility with applications to Morphodynamics on the Storm-dominated Sable Island Bank, Scotian Shelf. Geological Survey of Canada Open File 6155.

Li, M.Z., Shaw, J., Todd, B.J., Kostylev, V.E. and Wu, Y. 2014. Sediment transport and development of banner banks and sandwaves in an extreme tidal system: Upper Bay of Fundy, Canada. Continental Shelf Research, 83: 86-107.

Luff, R., and Moll, A. 2004. Seasonal dynamics of the North Sea sediments using a threedimensional coupled sediment-water model system. Continental Shelf Research, 24: 1099-1127.

Lynch, D. R., Ip, J.T.C., Naimie, C.E., and Werner, F.E. 1996. Comprehensive coastal circulation model with application to the Gulf of Maine. Continental Shelf Research, 16: 875906.

Miller, M.C., McCave, I.N. and Komar, P.D. 1977. Threshold of sediment motion under unidirectional currents. Sedimentology, 24: 507-527.

Mulligan et al. (2013) Mulligan, R.P., Smith, P.C., Hill, P.S., Tao, J., and van Proosdij, D. 2013. Effects of tidal power generation on hydrodynamics and sediment processes in the upper Bay of Fundy, 4th Specialty Conference on Coastal, Estuary and Offshore Engineering, Montréal, Québec, May 29 to June 1 2013, 1-10.

Neumeier, U., Ferrarin, C., Amos, C.L., Umgeisser, G. and Li, M.Z. 2008. SEDTRANS05: An improved sediment-transport model for continental shelves and coastal waters with a new algorithm for cohesive sediments. Computers and Geoscience, 34: 1223 - 1242. 
Nittrouer, C.A. and Wright, L.D. 1994. Transport of particles across continental shelves. Reviews of Geophysics, 32: 85-113.

O'Reilly, C.T., Solvason, R., Solomon, C. 2005. "Where are the World's Largest Tides?" In Bedford Institute of Oceanography Annual Report, 2004, Edited by Ryan, J., pp. 44-46.

Parrott, D.R., Cranston, R.E., Li, M.Z., Parsons, M.B., and Kostylev, V. 2002. Monitoring and evaluation of conditions at the Black Point offshore disposal site. Technical Report submitted to Environment Canada, $151 \mathrm{pp}$.

Parrott, D. R., Todd, B. J., Shaw, J., Kostylev, V., Hughes Clarke, J. E., Griffin, J., Lamplugh, M., 2010. Multibeam bathymetry surveys of the Bay of Fundy, Canada - progress to November 2009. Atlantic Geology, 46: p. 63-64.

Percy, J.A., Wells, P.G., Evans, A.J., and Gordon, D.C. Jr. 1997. Fundy Marine Ecosystem Science Project: Chapter 7 Workshop Synthesis. In Bay of Fundy Issues: a scientific overview, Edited by Percy, J.A. Wells, P.G. and Evans, A.J., Workshop Proceedings, Wolfville, NS, January 29 to February 1, 1996.

Porter-Smith, R., Harris, P.T., Andersen, O.B., Coleman, R., Greenslade, D., and Jenkins, C.J. 2004. Classification of the Australian continental shelf based on predicted sediment threshold exceedance from tidal currents and swell waves. Marine Geology, 211: 1- 20.

Qi, J., Chen, C., Beardsley, R.C., Perrie, W., Lai, Z. and Cowles, G. 2009. An unstructured-grid finite-volume surface wave model (FVCOM-SWAVE): implementation, validations and applications. Ocean Modelling, 28: 153-166. doi:10.1016/j.ocemod. 2009.01.007.

Roland, A., Zhang, Y. J., Wang, H.V., Meng, Y., Teng, Y. -C., Maderich, V., Brovchenko, I., Dutour Sikirić, M., Zanke, U. 2012. A fully coupled 3D wave-current interaction model on unstructured grids. Journal of Geophysical Research, 117: C00J33.

Rouse, H. 1937. Modern conceptions of the mechanics of turbulence. Transactions of the American Society of Civil Engineers, 102: 463-505.

Shaw, J., Todd, B.J., and Li, M.Z. 2014. Geologic insights from multibeam bathymetry and seascape maps of the Bay of Fundy, Canada. Continental Shelf Research, 83: 53-63.

Shaw, J., Todd, B.J., Li, M.Z., Wu, Y. 2012. Anatomy of the tidal scour system at Minas Passage, Bay of Fundy. Marine Geology, 323-325: 123-134.

Swail, V.R., Cardone, V.J., Ferguson, M., Gummer, D.J., Harris, E.L., Orelup, E.A. and Cox, A.T. 2006. The MSC50 Wind and Wave Reanalysis. 9th International Workshop On Wave Hindcasting and Forecasting, September 25-29, 2006, Victoria, B.C. Canada.

Tang, C.L., Yao, T., Perrie, W., Detracey, B.M., Toulany, B., Dunlap, E. and Wu, Y. 2008. BIO 
ice-ocean and wave forecasting models and systems for Eastern Canadian waters. Canadian Technical Report of Hydrography and Ocean Science No. 261, Ottawa, Ontario, Fisheries and Oceans Canada.

Tao, J., Hill, P.S., Mulligan, R.P., and Smith, P.C. 2014. Seasonal variability of total suspended matter in Minas Basin, Bay of Fundy. Estuarine, Coastal and Shelf Science, 151: 169-180.

Todd, B.J., Shaw, J., Li, M.Z., Kostylev, V.E., and Wu,Y. 2014. Distribution of subtidal sedimentary bedforms in a macrotidal setting: the Bay of Fundy, Atlantic Canada. Continental Shelf Research, 83: 64-85.

Tolman, H.L. 2002. User Manual and system documentation of WAVEWATCH-III Version 2.22. Technical Note. U.S. Depart. of Commerce.

Ulses, C., Estournel, C., Durrieu de Madron, X., \& Palanques, A. 2008. Suspended sediment transport in the Gulf of Lions (NW Mediterranean): Impact of extreme storms and floods. Continental Shelf Research, 28: 2048-2070.

Warner, J. C., Sherwood, C. R., Signell, R. P., Harris, C., \& Arango, H. G. 2008a. Development of a three-dimensional, regional, coupled wave, current, and sediment-transport model.

Computers and Geosciences, 34:1284-1306.

Warner, J. C., Butman, B., and Dalyander, P. S. 2008b. Storm-driven sediment transport in Massachusetts Bay. Continental Shelf Research, 28: 257-282.

Wu, Y., Chaffey, J., Greenberg, D., Colbo, K. and Smith, P. 2011a. Sediment transport patterns in the upper Bay of Fundy: a numerical study. Continental Shelf Research, 31: 2041-2053.

Wu, Y., Tang, C.C.L., Li, M.Z. and Prescott, R.H. 2011b. Modelling extreme storm-induced currents over the Grand Banks. Atmosphere-Ocean, 49: 259-269.

Wu, Y., Tang, C.L. and Hannah, C. 2012. The circulation of eastern Canadian seas. Progress in Oceanography, 106: 28-48.

Yao, T., Tang, C.L., and Peterson, I.K. 2000. Modeling the seasonal variation of sea ice in the Labrador Sea with a coupled multicategory ice model and the Princeton ocean model. Journal of Geophysical Research, 105: 1153-1166.

Zhang, Y., Swift, D.J.P., Fan, S., Niedoroda, A.W., Reed, C.W. 1999. Two-dimensional numerical modeling of storm deposition on the northern California shelf. Marine Geology, 154: $155-16$. 
Figure Captions

Figure 1 Map of Bay of Fundy with location names. Additional location names are shown in Figure 9.

Figure 2 Maps of (a) modelling domain with color-coded bathymetry (meter) and unstructured tidal model grid, and (b) interpolated mean grain size data (in meters) of the Bay of Fundy.

Figure 3 Root Mean Square (RMS) tidal current speed (a), maximum tidal current speed (b) and mean circulation current speed (c) in the Bay of Fundy. All are in $\mathrm{m} \mathrm{s}^{-1}$.

Figure 4 Maps of (a) mean significant wave height (m), (b) peak spectral wave period (s) and (c) maximum significant wave height $(\mathrm{m})$ in the Bay of Fundy. Wave data were not available for the head of Chignecto Bay and Minas Basin.

Figure 5 Magnitude of tidal current shear velocity $\left(\mathrm{a} ; \mathrm{m} \mathrm{s}^{-1}\right)$ and sediment mobilization frequency by tides (b; log scale time percent).

Figure 6 Magnitude of wave shear velocity $\left(\mathrm{a} ; \mathrm{m} \mathrm{s}^{-1}\right)$ and sediment mobilization frequency by waves (b; log scale time percent).

Figure 7 Magnitude of combined wave-current shear velocity $\left(\mathrm{a} ; \mathrm{m} \mathrm{s}^{-1}\right)$ and sediment mobilization frequency by the combined waves and current (b; log scale time percent).

Figure 8 Current speed $\left(\mathrm{m} \mathrm{s}^{-1}\right)$ and direction of (a) spring peak flood and (b) spring peak ebb.

Figure 9 Spring residual tidal current $\left(\mathrm{m} \mathrm{s}^{-1}\right)$ for the upper (a) and lower (b) Bay of Fundy.

Figure 10 Model-predicted bedload (a) and suspended load (b) sediment transport flux ( $\mathrm{kg} \mathrm{m}^{-1} \mathrm{~s}^{-}$

${ }^{1}$ ) for spring peak flood in the Bay of Fundy.

Figure 11 Model-predicted total-load sediment transport flux $\left(\mathrm{kg} \mathrm{m}^{-1} \mathrm{~s}^{-1}\right)$ for spring peak flood (a) and peak ebb (b).

Figure 12 Net sediment transport flux $\left(\mathrm{kg} \mathrm{m}^{-1} \mathrm{~s}^{-1}\right)$ averaged over two spring tidal cycles (over September 9-10, 2009) for the upper (a) and lower (b) Bay of Fundy.

Figure 13 Maps of (a) regionalization of relative importance of seabed disturbance by various processes, (b) Seabed Disturbance Index (SDI) and (c) Sediment Mobility Index (SMI) for the Bay of Fundy. Blank patches in (c) are areas of zero sediment mobility. See text for definitions of disturbance types, SDI and SMI.

Figure 14 Distribution of backscatter strength in the Bay of Fundy as proxy of substrate types. Light grey indicates very low strength over mud (silt and clay). Greenish light grey indicates low 
strength over sand. Blue indicates high strength over gravelly sediments or bedrock. 


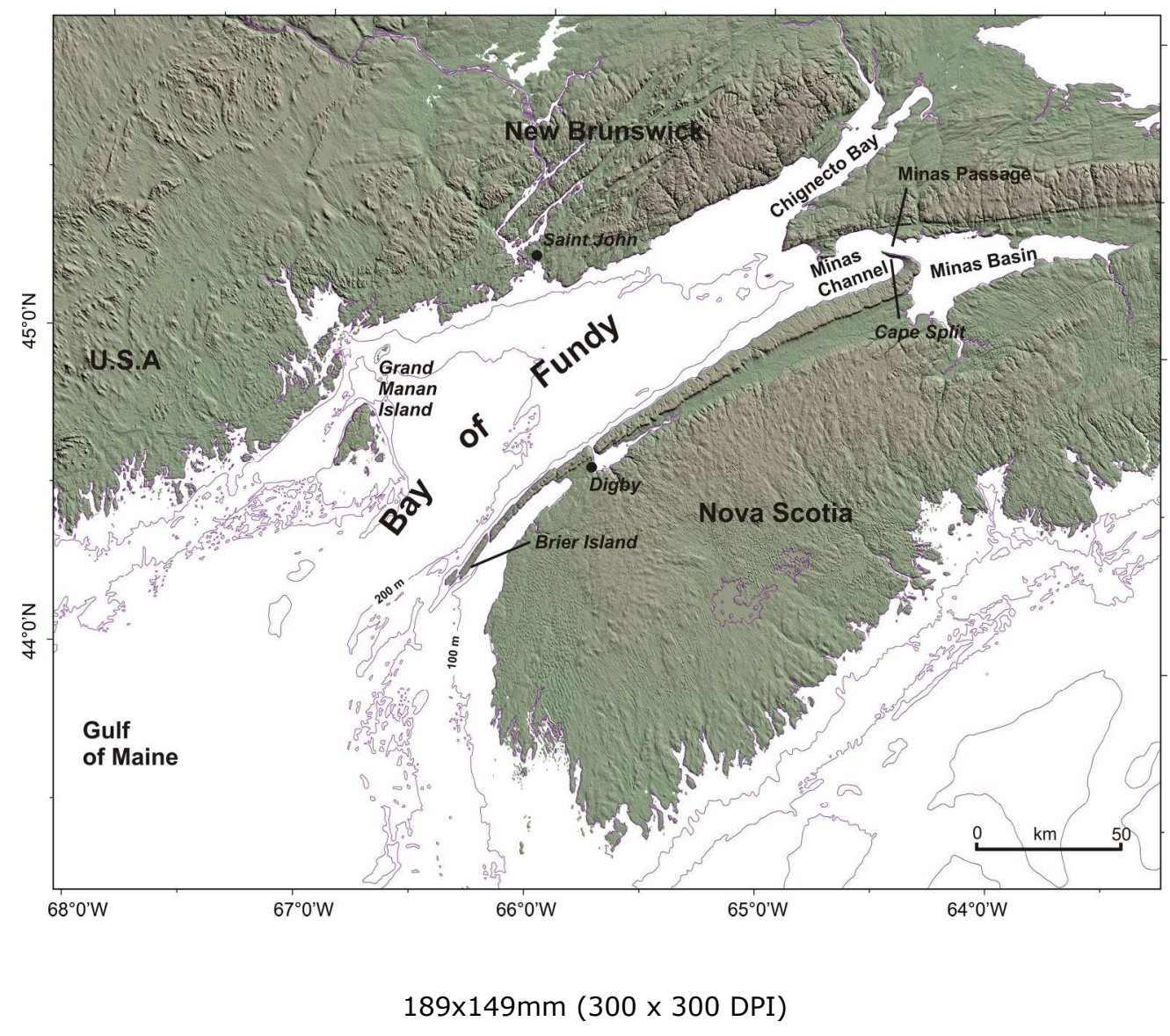




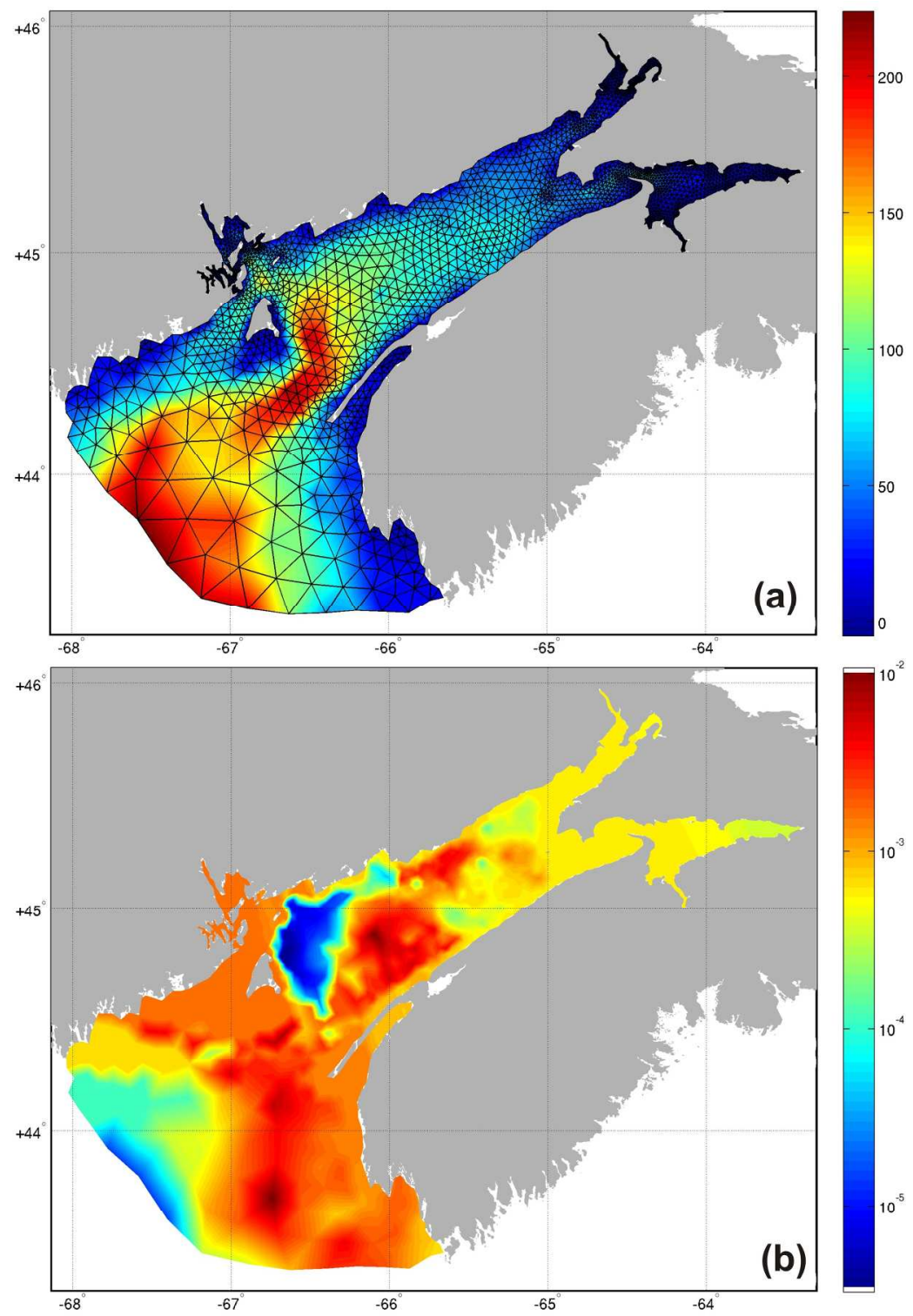

$172 \times 261 \mathrm{~mm}(300 \times 300 \mathrm{DPI})$ 

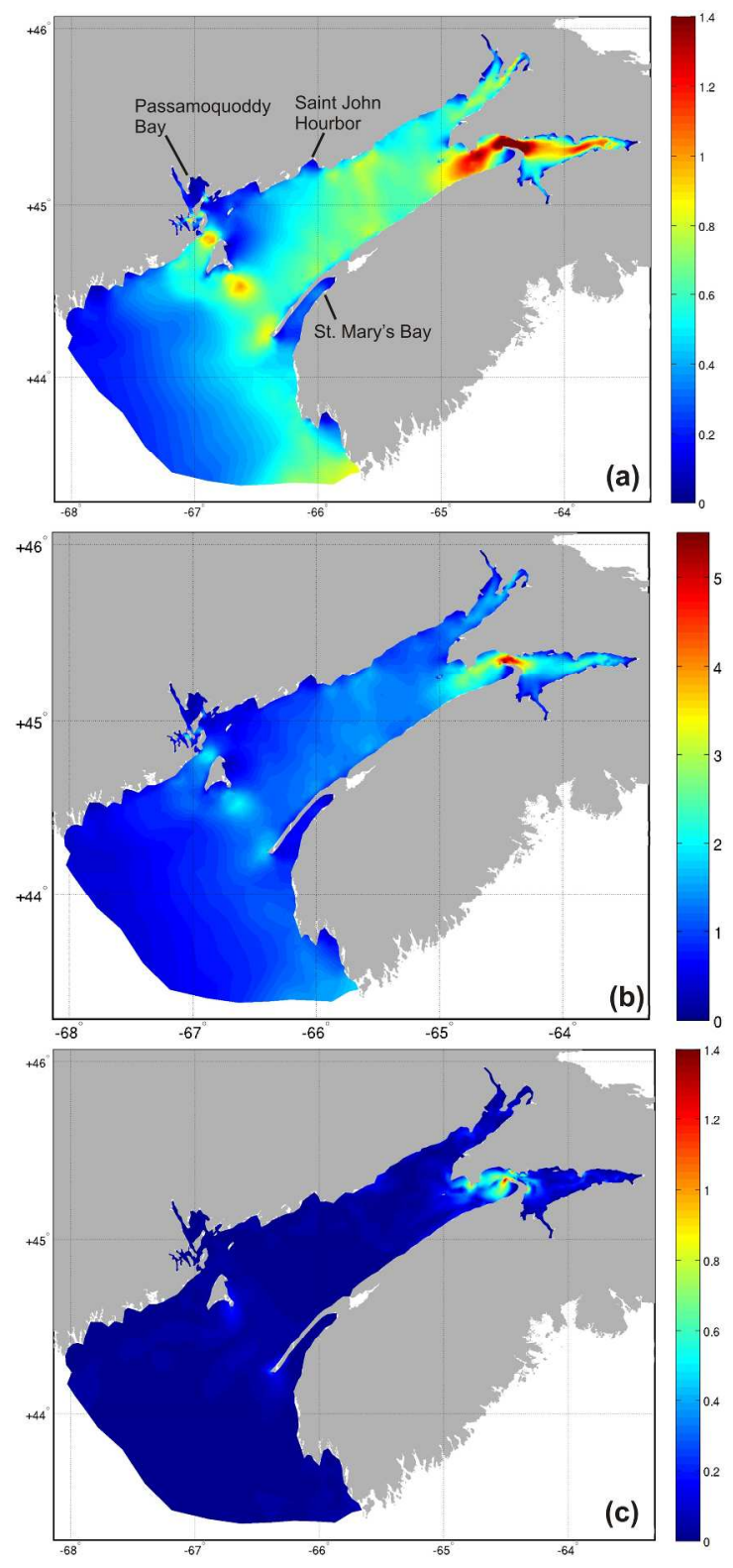

$214 \times 463 \mathrm{~mm}(300 \times 300$ DPI $)$ 

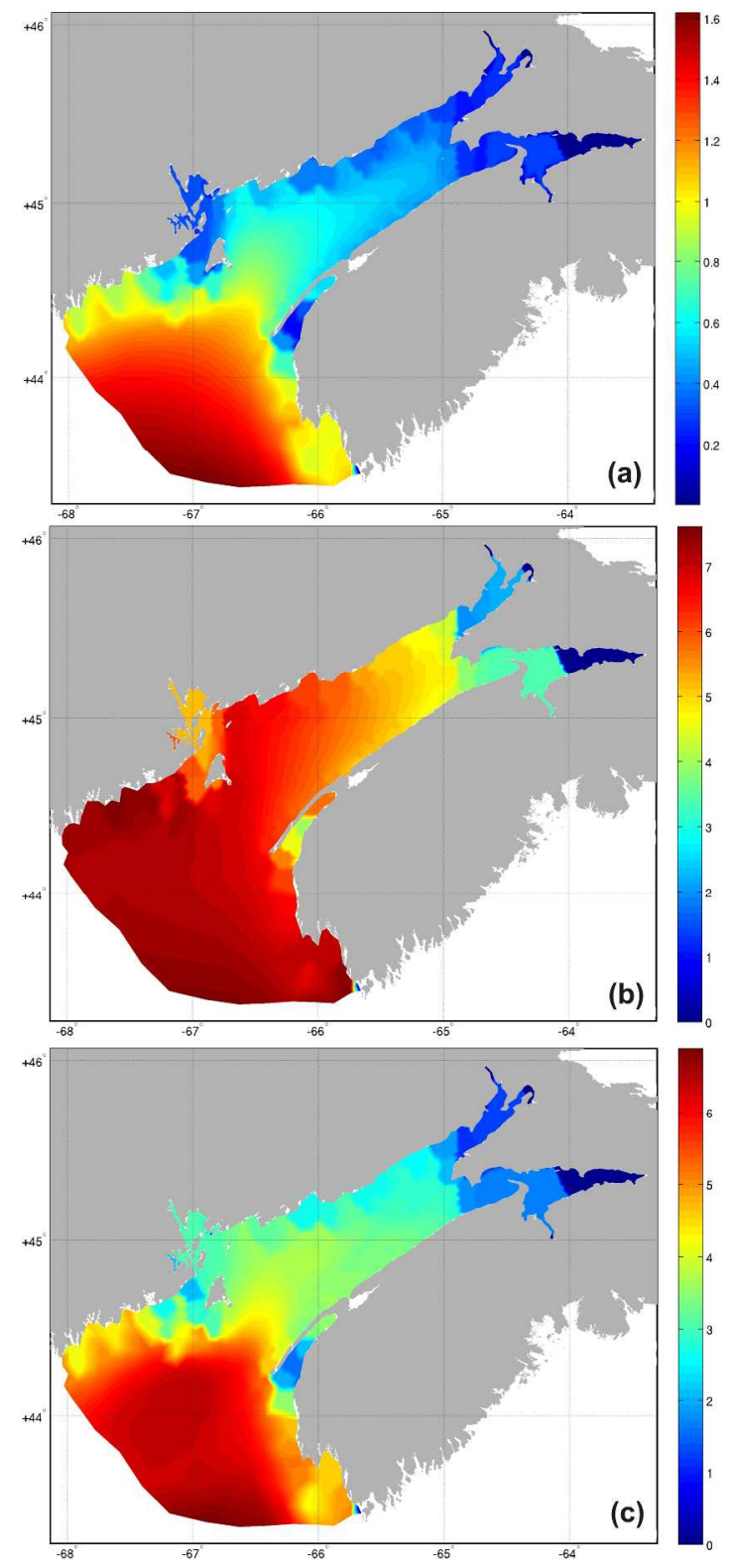

$212 \times 467 \mathrm{~mm}(300 \times 300 \mathrm{DPI})$ 

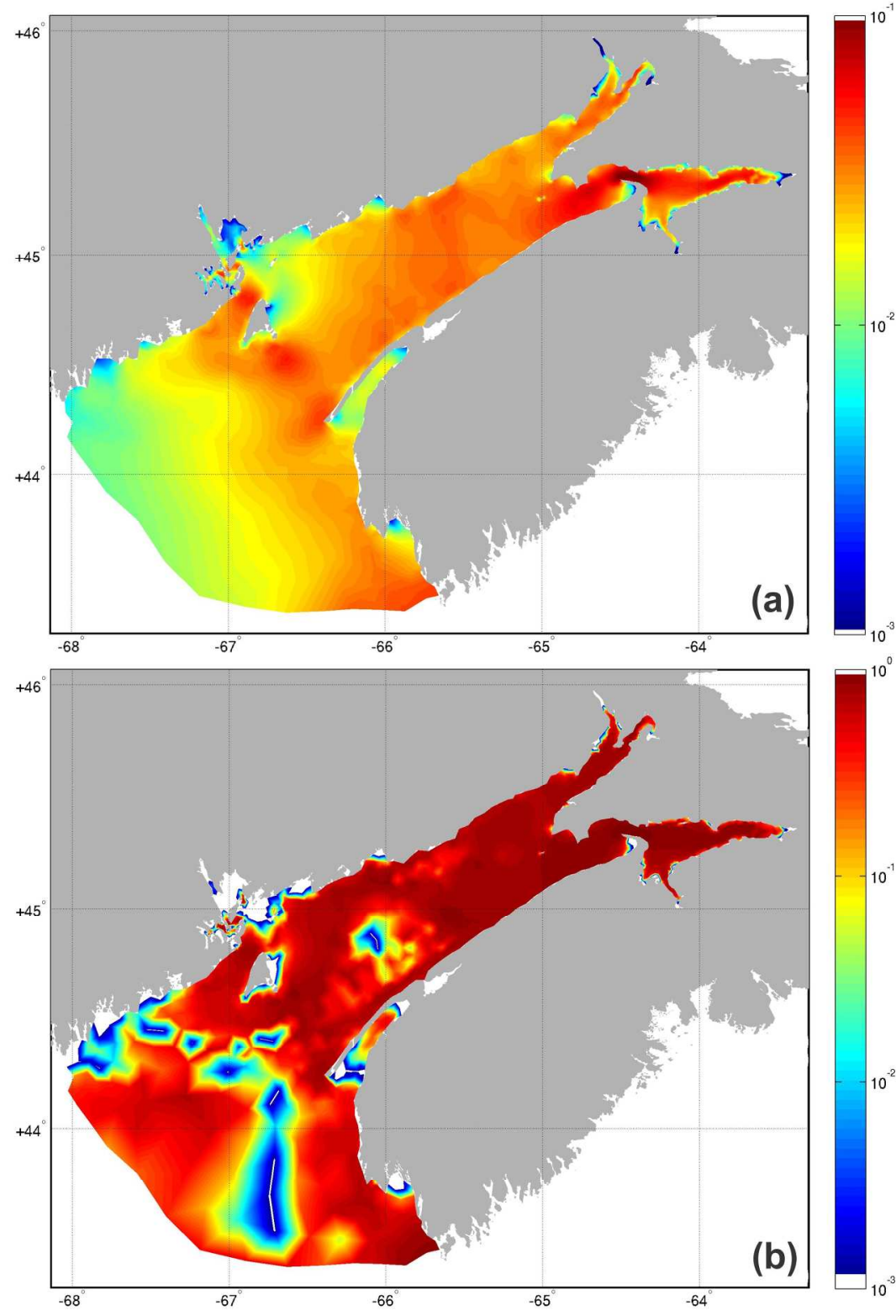

$168 \times 246 \mathrm{~mm}(300 \times 300 \mathrm{DPI})$ 

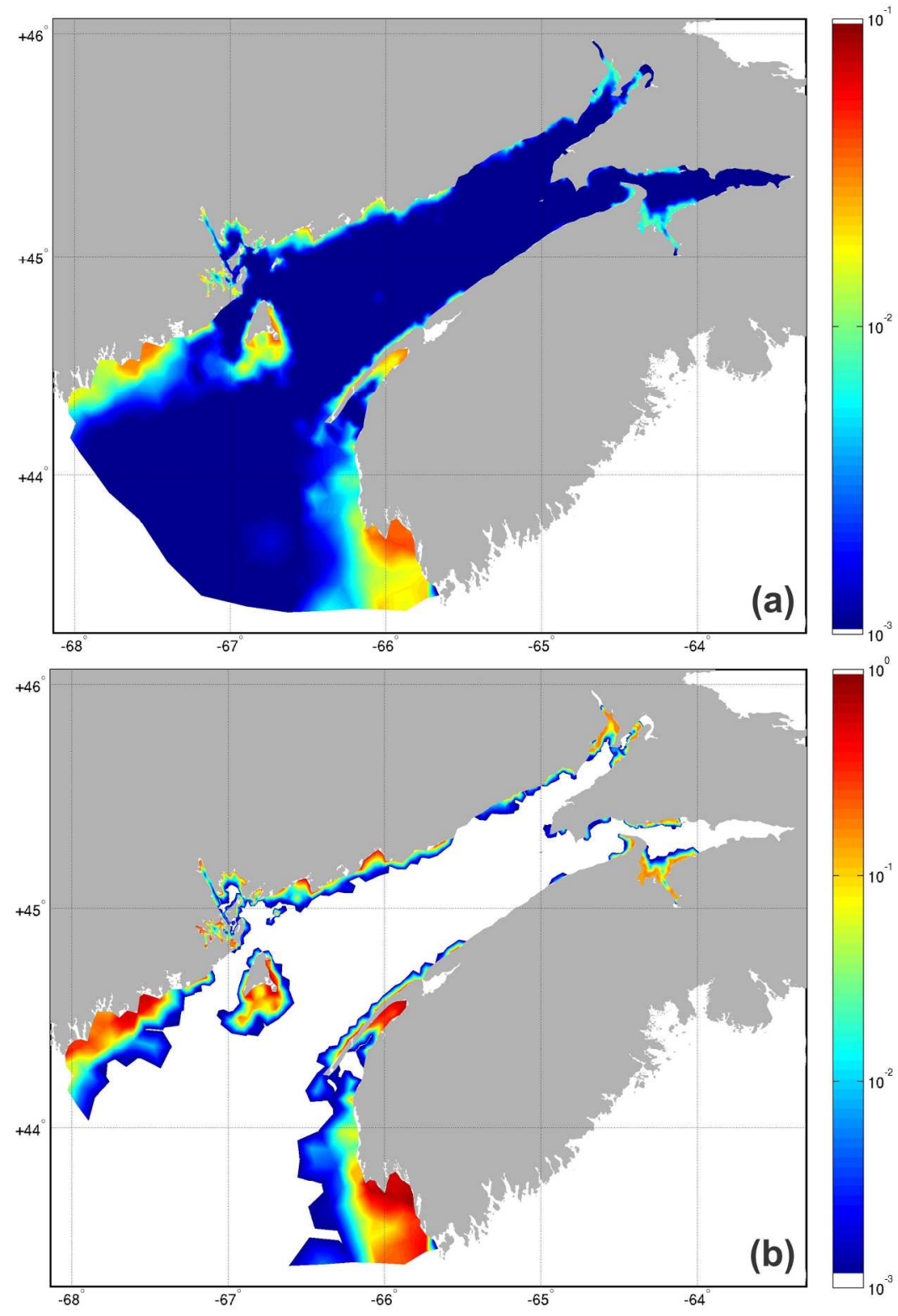

$169 \times 249 \mathrm{~mm}(300 \times 300 \mathrm{DPI})$ 


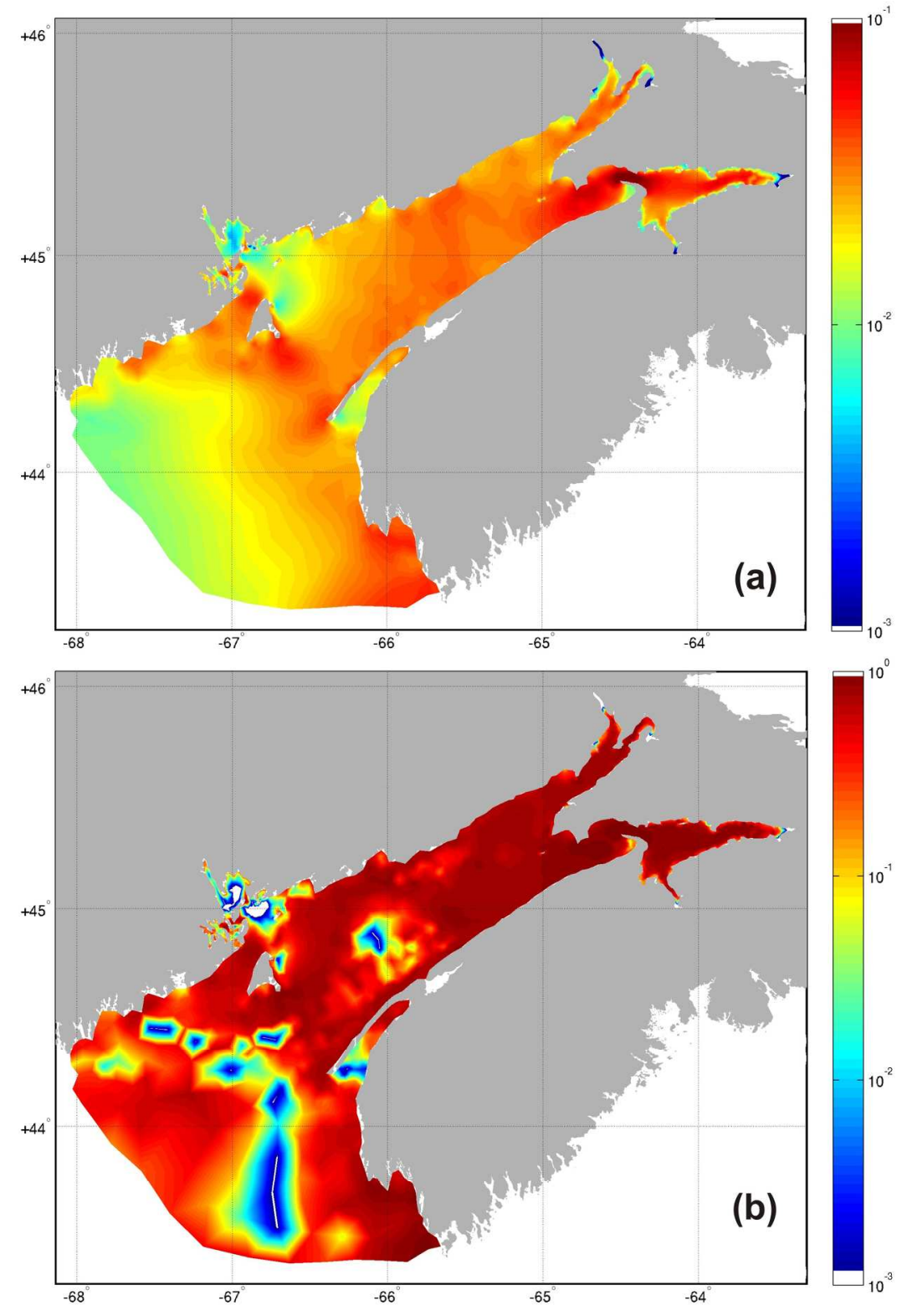

$168 \times 249 \mathrm{~mm}(300 \times 300$ DPI $)$ 


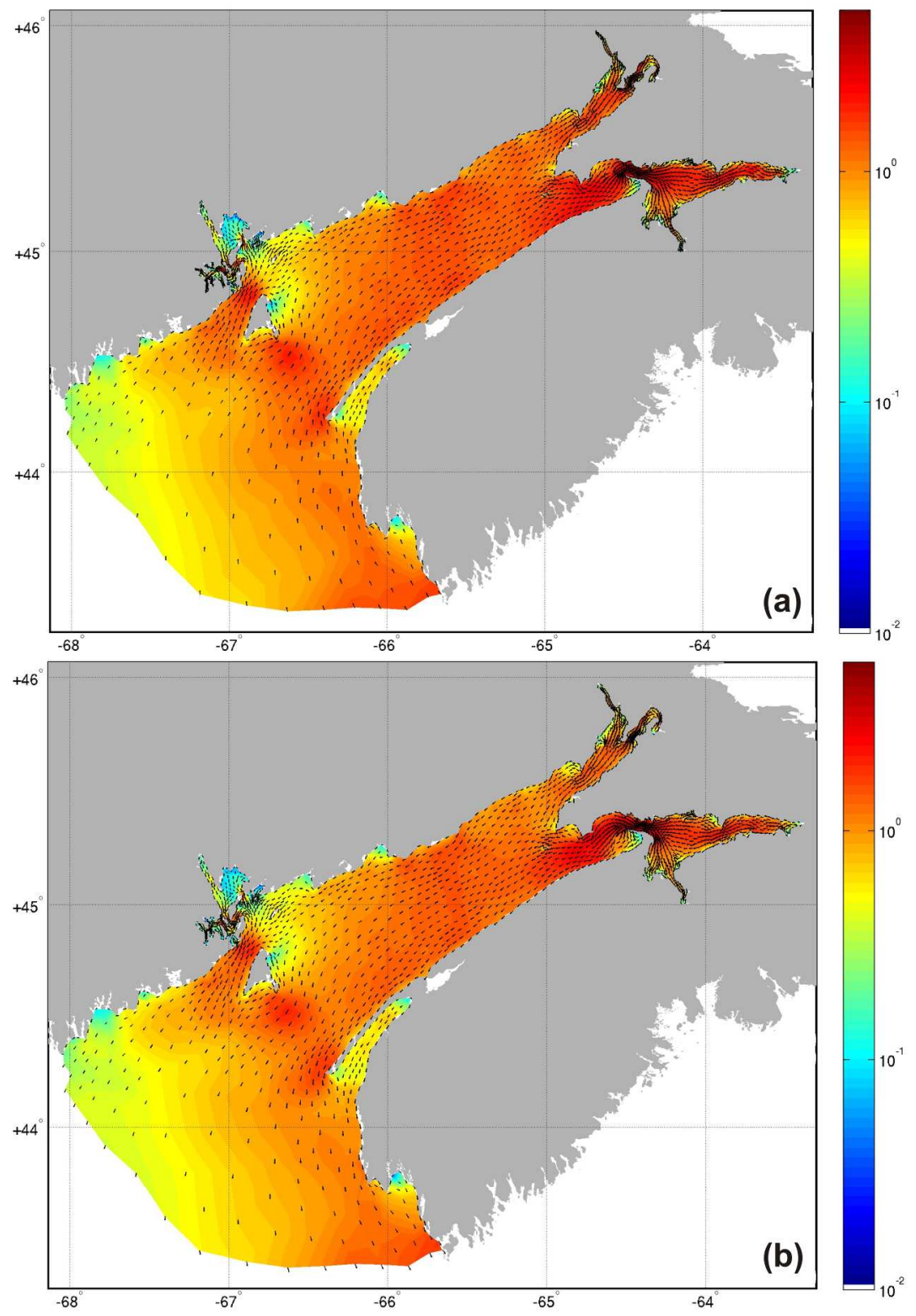

$197 \times 286 \mathrm{~mm}(300 \times 300$ DPI $)$ 

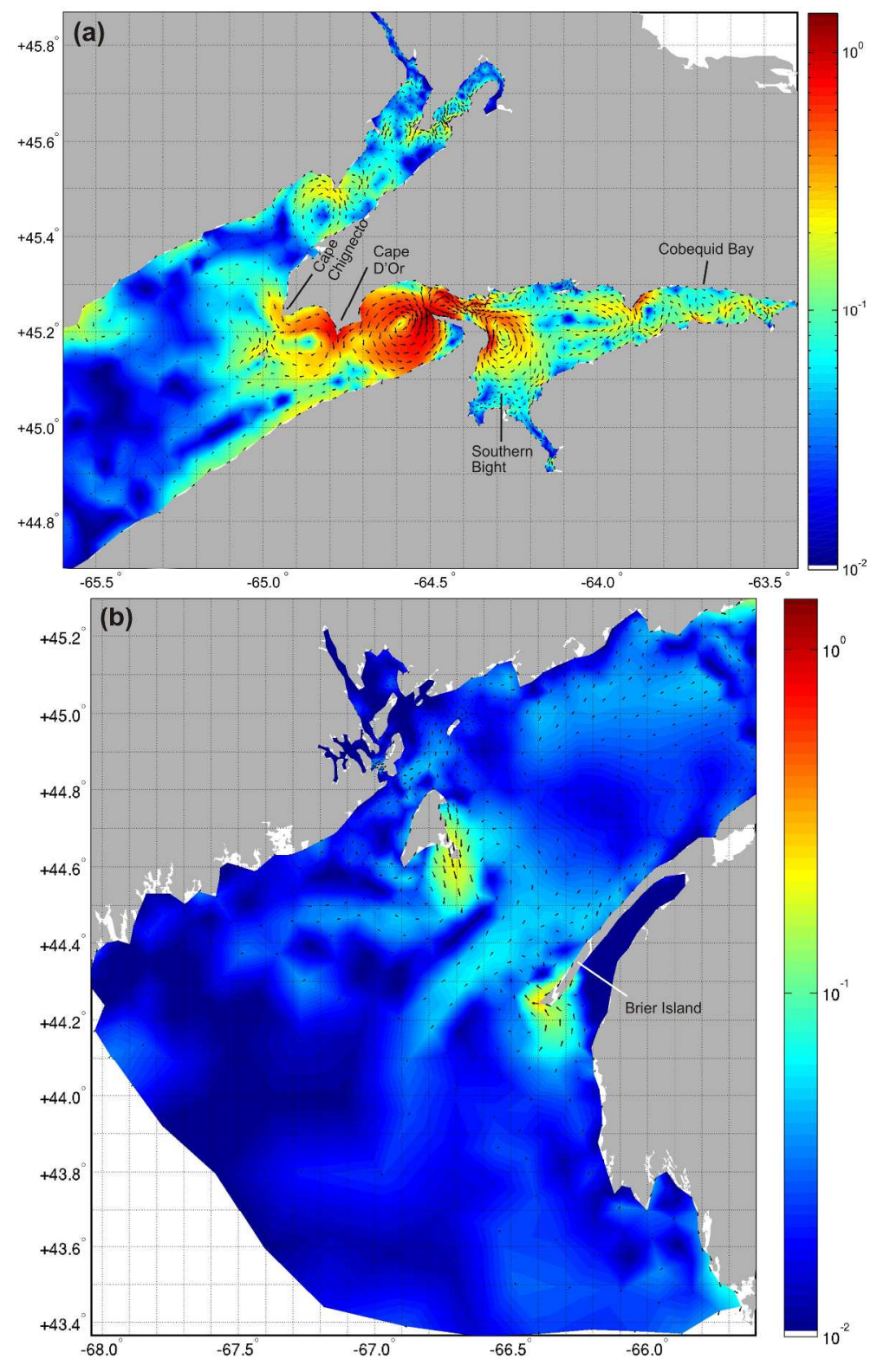

$251 \times 397 \mathrm{~mm}(300 \times 300$ DPI) 

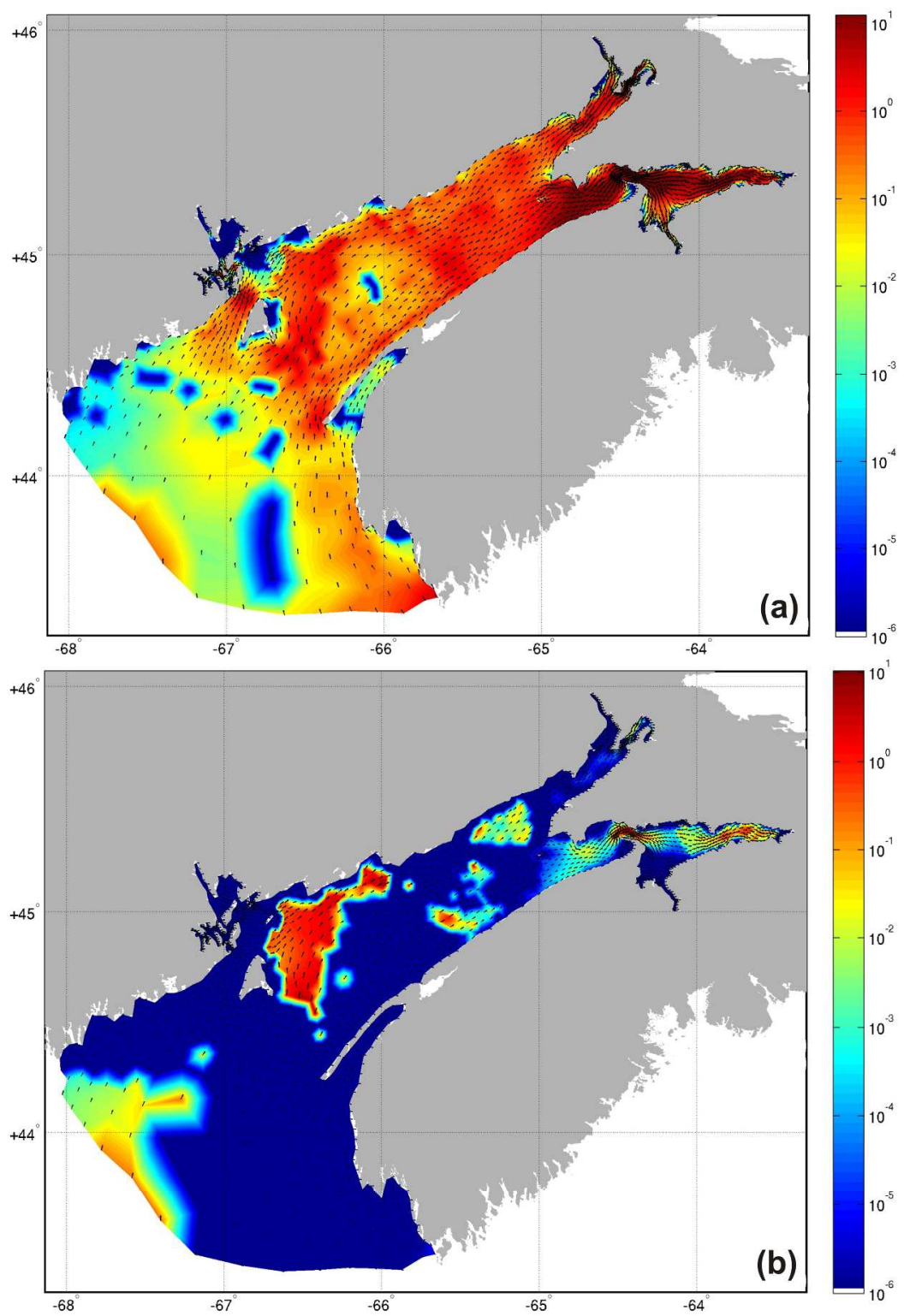

$200 \times 296 \mathrm{~mm}(300 \times 300$ DPI $)$ 

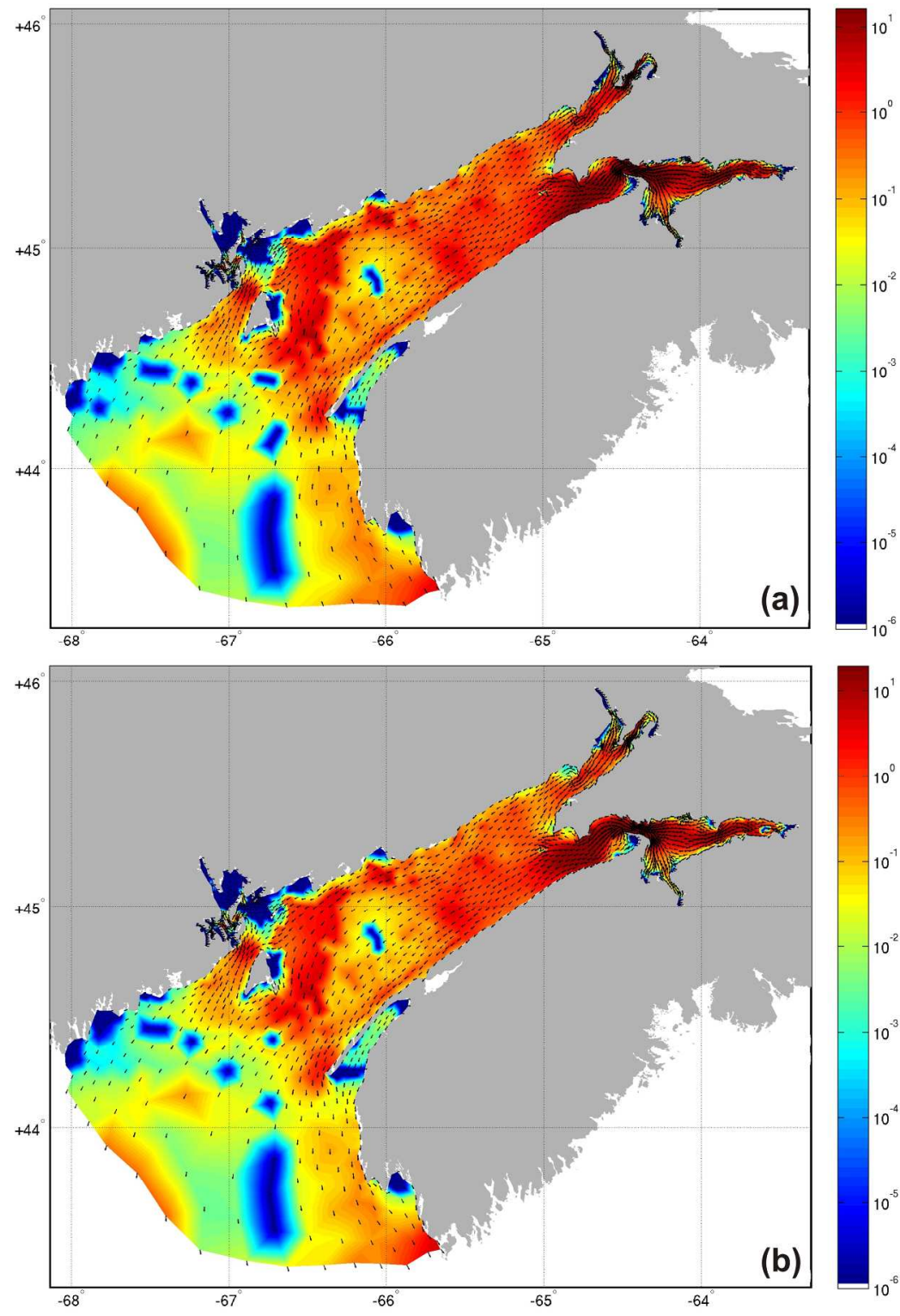

$201 \times 294 \mathrm{~mm}(300 \times 300$ DPI $)$ 

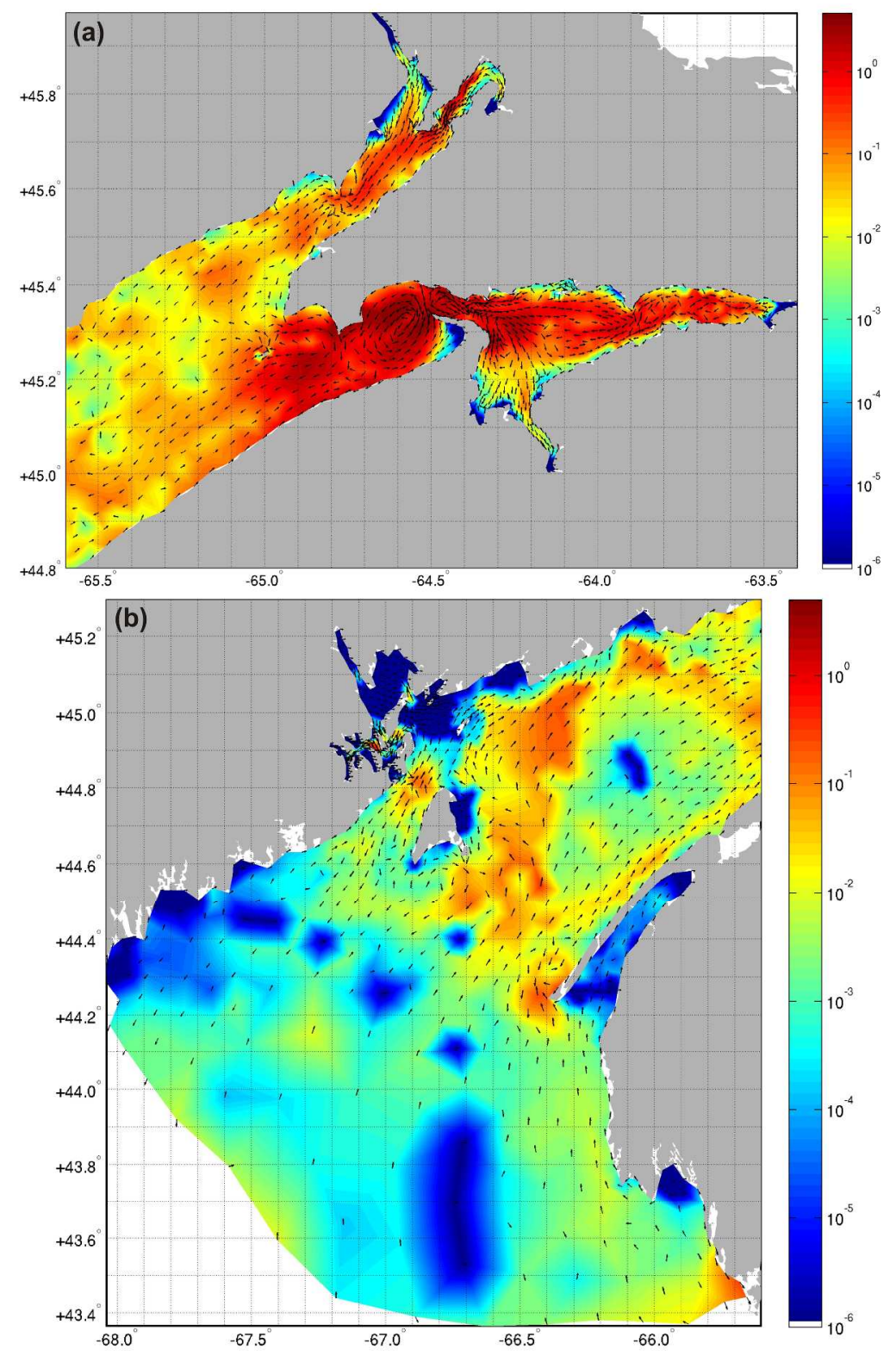

$250 \times 385 \mathrm{~mm}(300 \times 300$ DPI $)$ 


\section{Unable to Convert Image}

The dimensions of this image (in pixels) are too large to be converted. For this image to convert, the total number of pixels (height $x$ width) must be less than $40,000,000$ (40 megapixels). 


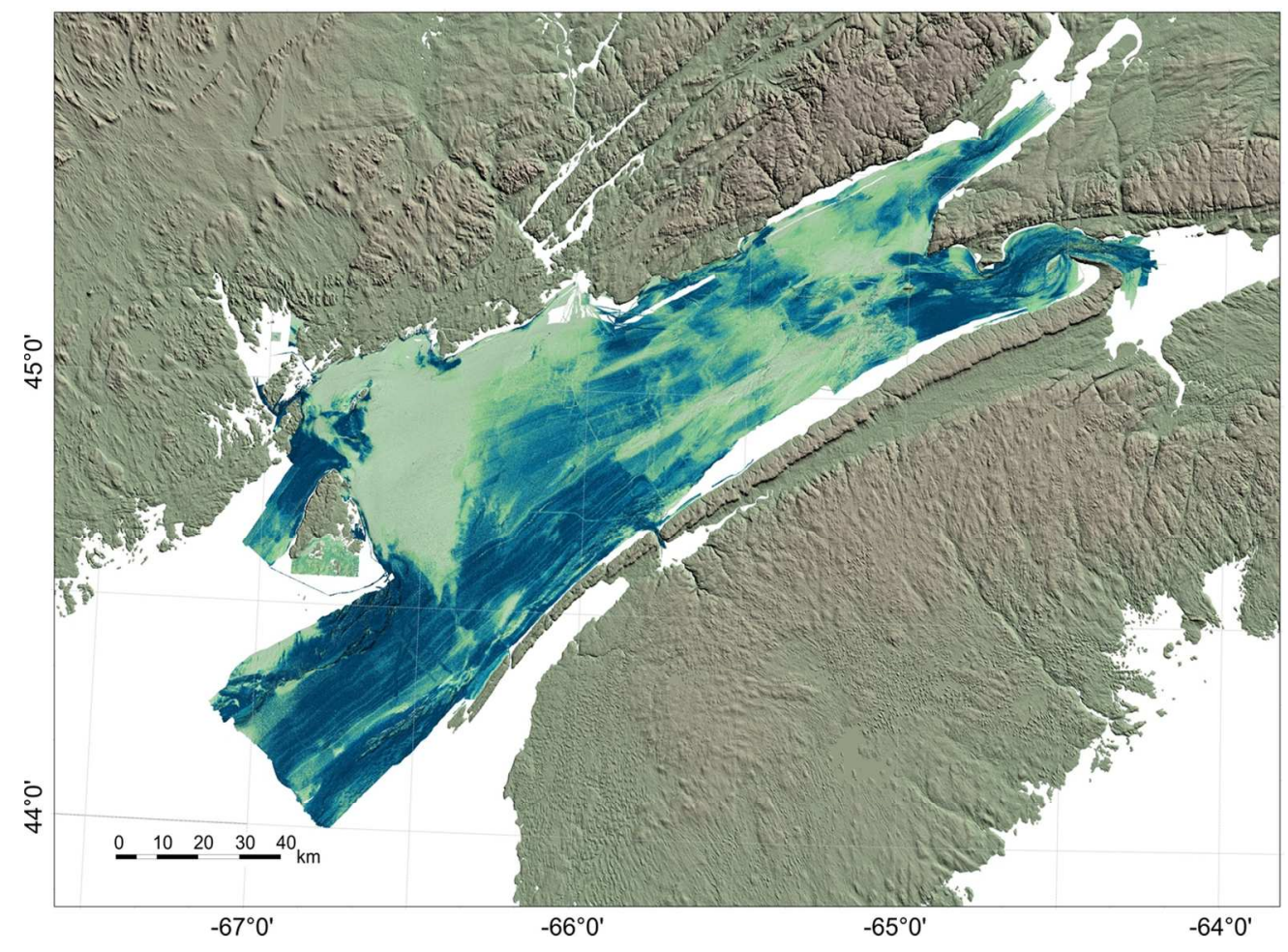

$121 \times 89 \mathrm{~mm}(300 \times 300 \mathrm{DPI})$ 